\title{
Catalogue, distribution, taxonomic notes, and conservation of the Western Palearctic endemic hunchback beetles (Tenebrionidae, Misolampus)
}

\author{
Natalia Rosas-Ramos ${ }^{1,2}$, Paloma Mas-Peinado ${ }^{2,3}$, Diego Gil-Tapetado ${ }^{2,4}$, \\ Ernesto Recuero ${ }^{2}$, José L. Ruiz ${ }^{5}$, Mario García-París²
}

I Departamento de Biología Animal (Área de Zoología), Facultad de Biología (Edificio de Farmacia, planta 5), Universidad de Salamanca, Campus Miguel de Unamuno s/n, 37007 Salamanca, Spain 2 Departamento de Biodiversidad y Biología Evolutiva. Museo Nacional de Ciencias Naturales, MNCN-CSIC. cl José Gutiérrez Abascal, 2. 28006, Madrid, Spain 3 Centro de Investigación en Biodiversidad y Cambio Global CIBC-UAM, Facultad de Ciencias, Universidad Autónoma de Madrid, c/Darwin 2, 28049-Madrid, Spain 4 Departamento de Biología, Ecología y Evolución, Facultad de Ciencias Biologicas, Universidad Complutense de Madrid, cl José Antonio Novais, 12, 28040-Madrid, Spain 5 Instituto de Estudios Ceuties. Paseo del Revellín, 30. 51001 Ceuta, Spain

Corresponding author: Mario García-París (mparis@mncn.csic.es)

Academic editor: Aaron Smith | Received 21 April 2020 | Accepted 10 July 2020 | Published 24 August 2020

http://zoobank.org/7D9006BB-8323-4F73-8A41-D487EBEA297A

Citation: Rosas-Ramos N, Mas-Peinado P, Gil-Tapetado D, Recuero E, Ruiz JL, García-París M (2020) Catalogue, distribution, taxonomic notes, and conservation of the Western Palearctic endemic hunchback beetles (Tenebrionidae, Misolampus). ZooKeys 963: 81-129. https://doi.org/10.3897/zookeys.963.53500

\begin{abstract}
Hunchback darkling beetles of the Ibero-Maghrebian genus Misolampus Latreille, 1807 (Tenebrionidae, Stenochiinae) encompass six species: M. gibbulus (Herbst 1799), M. goudotii Guérin-Méneville, 1834, $M$. lusitanicus Brême, 1842, M. ramburii Brême, 1842, M. scabricollis Graells, 1849, and M. subglaber Rosenhauer, 1856. Previously known distribution ranges of the species were delineated using many old records, the persistence of such populations being questionable under the current situation of global biodiversity loss. Additionally, the status of geographically isolated populations of the genus have been the subject of taxonomic controversy. An exhaustive bibliographical revision and field search was undertaken, and the Misolampus collection of the Museo Nacional de Ciencias Naturales (MNCN-CSIC) was revised. The aims are to (i) provide an updated geographic distribution range for the species of Misolampus; (ii) to determine the taxonomic status of controversial populations; (iii) to provide a catalogue for Misolampus; and (iv) to discuss the conservation status of these saproxylic beetles. As a result, a catalogue including synonymies and type localities, geographical records, diagnoses, and information on natural history for all species
\end{abstract}

Copyright Natalia Rosas-Ramos et al. This is an open access article distributed under the terms of the Creative Commons Attribution License (CC BY 4.0), which permits unrestricted use, distribution, and reproduction in any medium, provided the original author and source are credited. 
of Misolampus is presented. The results reveal that the distribution ranges of the species of Misolampus have not undergone a reduction in the last century, and indicate the presence of the genus in areas where it had never been recorded before. The morphological variability of $M$. goudotii drove the proposal of different taxa that are here formally synonymised as follows: $M$. goudotii Guérin-Méneville, $1834=M$. erichsoni Vauloger de Beaupré, 1900, syn. nov. = M. peyerimhoffi Antoine, 1926, syn. nov.

\section{Keywords}

Coleoptera, geographic range, morphological variability, new synonymies, population persistence, saproxylic, scientific collections, Stenochiinae

\section{Introduction}

Species identification is an essential process for almost all biodiversity studies and can constitute a major constraint for conservation evaluation and legislation due to the inherent difficulty of identifying many of the groups, the long time needed for processing the samples, and the extensive taxonomic experience that this process requires (Gauld et al. 2000; Guerra-García et al. 2008; Wheeler 2013; de Oliveira et al. 2020; Saoud 2020). Meeting this goal for megadiverse groups such as insects is often arduous considering the vast number of species that must be identified and the limited number of taxonomists, which make correct identification a very time-consuming process (De Carvalho et al. 2005; Evenhuis 2007; Wheeler 2008; Moore 2011; Yang et al. 2015). It is therefore necessary to create easy-to-use identification tools, such as visually enhanced guides, to overcome the difficulties involved in the identification process (Kirchoff et al. 2011). Easy-to-use tools are also a key instrument for biodiversity study and conservation, since they can be used by both specialists and non-specialists and their implementation improves outcome, thereby facilitating decision-making for conservation actions (Norton et al. 2000; Yang et al. 2015; Rosas-Ramos et al. 2019).

Tenebrionidae is one of the most species-rich families of beetles, with approximately 20,000 species worldwide and many more taxa yet to be described (Bousquet et al. 2018). The large number of species, combined with the high morphological diversity that this family exhibits (Matthews et al. 2010), can hinder species identification of tenebrionids. Thus, providing easy-to-use, photographically illustrated identification tools can greatly facilitate data acquisition on this group of beetles (e.g., Matthews and Bouchard 2008; Pérez-Vera and Ávila 2012). The problem represented by the local absence of taxonomists and lack of adequate identification tools for non-specialists, is often reflected in a general lack of appropriate identifications, use of not-actualised names, or worst, inclusion of misidentified specimens in scientific collections or databases (Vilgalys 2003; Guerra-García et al. 2008; Kholia and Fraser-Jenkins 2011; Shea et al. 2011). This situation renders Tenebrionidae collections of little use for any scientific purpose, as it can be easily recognised by their poor representation in biodiversity databases (e.g., GBIF - Gaiji et al. 2013). One example of this problem is represented by the saproxylic hunchback darkling beetles of the genus Misolampus Latreille, 1807, paradoxically one 
of the better studied genera of Tenebrionidae at taxonomic and phylogenetic levels in the Western Palearctic Region (Palmer 1998; Palmer and Cambefort 2000).

The genus Misolampus [type species: Misolampus hoffmannseggii Latreille, 1807 (= Pimelia gibbula Herbst, 1799), by monotypy], currently included within Cnodalonini Oken, 1843, in the subfamily Stenochiinae Kirby, 1837 (= Coelometopinae Schaum, 1859; = Cnodaloninae; see Bouchard et al. 2005, 2011), encompasses six species: M. gibbulus (Herbst 1799), M. goudotii Guérin-Méneville, 1834, M. lusitanicus Brême, 1842, $M$. ramburii Brême, 1842, M. scabricollis Graells, 1849, and $M$. subglaber Rosenhauer, 1856 (Löbl et al. 2008; Martínez Fernández 2018), all of them linked to woodlands (Español 1949, 1954b; Molino Olmedo 1996; Palmer 1998). Five of them are endemic to the Iberian Peninsula, while $M$. goudotii is distributed throughout Morocco, Algeria and the Balearic Islands (Löbl et al. 2008). Reitter (1917), Antoine (1949, 1954), and Español (1949) provided identification keys for the species of Misolampus, and Palmer (1998) illustrated the female genitalia and specific diagnostic characters. Palmer (1998) and Palmer and Cambefort (2000) presented analyses of their geographic distribution and phylogenetic relationships, based on morphological traits. However, a search in the GBIF database (https://www.gbif. org; searched 22-mar-2020), only retrieved a total of 49 records for Misolampus (once records for other genera were discarded), three of them identified at genus level, and at least one misidentified species; 14 of 49 had geographic coordinates data, eleven of which corresponded to a single locality. Excluding all additional specimens with imprecise locality data, fewer than 30 specimens remained available for scientific use.

Despite database records shortfall, the distribution ranges of the species of $\mathrm{Mis}$ olampus are relatively well known (Palmer 1998). Nevertheless, a few new eccentric geographical records have recently been published, suggesting that the distribution areas might be larger than what is currently recognised (Ibáñez Orrico 2002; Pérez and López-Colón 2010; Novoa et al. 2014). Regretfully, many of the specimens used to delineate the distribution areas of the species were collected between 50 and 100 years ago (Palmer 1998). The continuity of those populations through time, under the current scenario of drastic increase in land-use and climate change is, however, questionable (Vanwalleghem et al. 2017), all the more so given the saproxylic nature of these species, which often can lead to conservation issues (García-López et al. 2016).

In the light of these considerations, first, we aimed to provide an updated geographic distribution range for all the species of Misolampus, to evaluate their persistence in the areas where they were reported. For this purpose, we undertook a thorough bibliographical revision, an exhaustive field search, and we revised the Misolampus collection of the Museo Nacional de Ciencias Naturales (MNCN-CSIC) in Madrid (Spain). Secondly, and as a result of the field data collection, we aimed to determine the taxonomic status of geographically isolated populations of the genus, including those that have been the subject of taxonomic controversy (Reitter 1917; Español 1949; París García et al. 2011). Thirdly, with all that information, we aimed to provide an easy to use, photographically illustrated catalogue for Misolampus, and to discuss the potential threats and conservation status of the species of the genus. 


\section{Materials and methods}

Field work to locate Misolampus was carried out by members of the research team for two periods, a non-intensive period from 1982 to 2000 in which specimens were collected, georeferenced, and dry-mounted for their morphological study, and a more intensive period from 2001 to 2013, with additional collections in 2019-2020, aimed to detect changes in populations previously known from records dating from the $19^{\text {th }}$ and $20^{\text {th }}$ centuries. Field data collection was carried out along most of the areas where the presence of the genus was documented (Spain, Portugal, and Morocco). Information on the location of previously known populations was obtained by undertaking an exhaustive bibliographic revision and by reviewing the Misolampus collection held at the MNCN (Museo Nacional de Ciencias Naturales, Madrid, Spain).

We studied 1304 specimens representing all known taxa of Misolampus (812 collected before 1945, and 492 collected after 1982). Of those, 355 specimens are preserved in ethanol, and 949 specimens dry-mounted (Table 1), all forming part of the entomological collections of the Museo Nacional de Ciencias Naturales (MNCN-CSIC, Madrid). The list of examined specimens is included in the corresponding paragraph of the species catalogue. Collectors are specified when different from authors or members of the research team; collector name is indicated for old collections only when printed in the labels; "ex." or "exx." is used to abbreviate "specimen" or "specimens".

Unresolved taxonomic issues, such as the validity of subspecies within the North African taxon, the specific assignation of the populations from Algarve (Reitter 1917; Español 1949), and taxonomic status of the isolated population from Ifni (Morocco) (París García et al. 2011), were addressed by comparing these problematic populations with specimens from near type localities, or from areas of undisputed taxonomy.

Distribution maps based on current data represent the extent of occurrence of each species following a relaxed modification of IUCN criteria (IUCN 2012). We performed species distribution models (SDMs) to obtain the potential distribution of each species (Kamiński et al. 2017). We used Maximum entropy algorithm (MaxEnt) (Elith et al. 2006, 2011) and the set of WorldClim v 2.0 environmental variables, with a resolution of $30 \mathrm{~s}(-1 \mathrm{~km})$ (Fick and Hijmans 2017). The SDMs were modelled considering the studied specimens as presences and generating pseudo-absences fol-

Table I. Specimens of Misolampus studied. Number of specimens by preservation mode (ethanol or dry-mounted) and date of collection (before 1945 or after 1982). The total number of specimens of each species is also provided.

\begin{tabular}{lccccc}
\hline \multicolumn{1}{c}{ Species } & Before 1945 & After 1982 & Dry-mounted & Alcohol & Total \\
\hline Misolampus gibbulus & 339 & 163 & 392 & 110 & 502 \\
Misolampus goudotii & 108 & 66 & 145 & 29 & 174 \\
Misolampus lusitanicus & 1 & 27 & 1 & 27 & 28 \\
Misolampus ramburii & 11 & 26 & 32 & 5 & 37 \\
Misolampus scabricollis & 310 & 178 & 328 & 160 & 488 \\
Misolampus subglaber & 43 & 32 & 51 & 24 & 75 \\
\hline
\end{tabular}


lowing Gil-Tapetado et al. (2018). This methodology creates a preliminary presenceonly coverage model based on the maximum and minimum values of each variable. Areas with environmental values that fall out of the maximum and minimum range were considered liable to be pseudo-absences. This is considered as a more reliable approach than generating pseudo-absences entirely at random. SDMs were run 50 times, with random test percentage set to 25 and "subsample" as the sampling technique. The model was validated by estimating the area under the curve (AUC) value (Fielding and Bell 1997). All SDMs have AUC > 0.95 (M. gibbulus: 0.958; M. goudotii: 0.965; M. lusitanicus: 0.998; M. ramburii: 0.963; M. scabricollis: 0.964; M. subglaber: 0.958).

To obtain morphological data, dry-mounted specimens were examined under a stereomicroscopy. Specimen length was measured in dorsal view as the distance between the anterior margin of the pronotum and the elytral apex (ignoring elytral convexity). The head was excluded from measurement since it is usually directed ventrally. Maximum width was measured as the distance between the outer edges of the elytra at approximately three-fourths of the elytral length, also in dorsal view. Photographs of live specimens were taken with a Nikon digital camera. Extended depth-of-focus images of dry-mounted specimens, were taken on a Leica M165C stereo-microscope, with a digital camera Leica DFC450, using the LAS X software from Leica Microsystems.

\section{Results}

Species catalogue, distribution, notes on natural history, and taxonomy

\section{Misolampus gibbulus (Herbst, 1799)}

Pimelia gibbula Herbst, 1799: 51. Terra typica: unknown: "Das vaterland ist mir unbekannt".

Misolampus hoffmannsegii Latreille, 1807: 161. Terra typica: "e Lusitania allatus". Latreille's (1807) species name has been often misspelled. Guérin-Méneville (18291838: 115, pl. 29; 1834: 27) spelled it as: " $M$. hoffmansegii" and " $M$. hoffmanseggii", respectively, Solier (1848: 185): "M. hoffmanseggii", and Laporte de Castelnau (1850: 204): " $M$. hoffmansseggii". Synonymy with $M$. gibbulus proposed by Solier (1848).

Misolampus gibbulus (Herbst, 1799): Solier 1848: 185.

Studied material. Portugal - Beja: Beja: 1 ex.; Beja, V-1909 (exp. del Museo): 1 ex.; São Martinho das Amoreiras, 200 m, 37³6'57.4"N, 08²7'57.3"W, 4-I-2013: 10 exx. - Evora: Evoramonte, 17-X-1992: 1 ex.; Monte São Bento, 353 m, 38³4'54.33"N, 756' 12.10"W, 11-III-2010: 1 ex.; Valverde, 232 m, 38³1'39.8"N, $8^{\circ} 00^{\prime} 25.4 " \mathrm{~W}, 4-\mathrm{X}-$ 2002: 1 ex.; - Faro: Alferce: 1 ex.; Alferce, V-1909 (Exp. del Museo): 2 exx.; carretera Monchique-Laranjeira [Gil Bordalo], 21-X-1992: 6 exx.; Foia, 742 m, 37 $17^{\circ} 29.4^{\prime \prime N}$, 083' 56.2"W, 4-I-2013: 1 ex.; Monchique, 439 m, 37²1'40.3"N, 08²32'23.6"W, 
4-I-2013: 8 exx.; San Marcos da Serra [São Marcos da Serra]: 2 exx.; San Marcos da Serra [São Marcos da Serra], V-1909 (exp. del Museo): 23 exx.; São Marcos da Serra, 140 m, 37² $21^{\prime} 02.5^{\prime \prime N}, 08^{\circ} 22^{\prime} 48.4^{\prime \prime W}, 3-I-2013: 24$ exx.; Sierra de Monchique, V-1909 (exp. del Museo): 1 ex.; Portalegre: Santo Antonio de Alcorrego, 150 m, 3858'59.5"N, 756'54.1"W, 18-IV-2013: 6 exx. Spain - Andalucía: Córdoba: Córdoba (Col. del Sr. Pérez Arcas): 2 exx.; Córdoba: 2 exx.; Córdoba, IV-1901 (Escalera leg.): 4 exx.; Córdoba, VI-1909 (Exp. del Museo): 3 exx.; Manueles, 30SUH82, 7-V1982 (M.A. Alonso Z. leg.): 1 ex.; Huelva: Barranco Riofrío [La Nava], 28-XII-1985: 1 ex.; Cala (C. Bolívar leg.): 15 exx.; Cortegana, Puerto del Corzo (hacia Gil Márquez), $664 \mathrm{~m}, 37^{\circ} 52^{\prime} 56.1^{\prime \prime N}, 06^{\circ} 50^{\prime} 42.3 " \mathrm{~W}, 3-\mathrm{I}-2013: 7$ exx.; Patrás, $397 \mathrm{~m}, 37^{\circ} 48^{\prime} 04.4^{\prime \prime N}$, 643'30.8"W, 1-V-2004: 3 exx.; Jaén: [3 km al SO de] Aldeaquemada, 25-IV-1992: 3 exx.; Lugar Nuevo, 24-X-1991: 2 exx.; Santa Elena, carretera hacia La Aliseda, 795 m, $38^{\circ} 20^{\prime} 53.1^{\prime \prime N}, 03^{\circ} 33^{\prime} 20.6^{\prime W}$ W, 28-XII-2010: 14 exx.; Santa Elena, 12-III-1901: 2 exx.; Santa Elena: 2 exx.; Sierra Morena: 1 ex.; Sevilla: Constantina: 1 ex.; - Castilla-La Mancha: Ciudad Real: Almadén (Belbeze leg.): 1 ex.; Navas de Estena: 1 ex.; Pueblo Nuevo del Bullaque, 7-XII-1992: 2 exx.; Puerto Madrona, 20-XI-1992: 8 exx.; Saceruela (Paz leg.): 1 ex.; Solana del Pino: Puerto Madrona, 38²5'07.3"N, 403'33.1"W, 06-III2012: 1 ex.; Toledo: Santa Cruz del R. [Retamar] (Paz leg.) (Col. del Sr. Pérez Arcas): 1 ex.; - Castilla y León: Ávila: Candeleda, XI-1933: 1 ex.; 8 km NE Hoyo de Pinares, 40³1'40.6"N, 4²0'04.5"W, 1-IV-2013: 2 exx.; Mombeltrán - Navalperal [de Pinares]: 1 ex.; Extremadura: Badajoz: Aljucén (Pacheco leg.): 2 exx.; Cáceres: Alcuéscar: I-1894: 3 exx.; Belvís de Monroy, 373 m, 3948'04.8"N, 5³7'01.1"W, 24-XII-2011: 6 exx.; Castillo de Trevejo, $714 \mathrm{~m}, 40^{\circ} 10^{\prime} 20.9^{\prime \prime N}, 6^{\circ} 46^{\prime} 48.9^{\prime \prime W}, 17-I V-2011: 1$ ex.; Valdemorales, $420 \mathrm{~m}, 39^{\circ} 12^{\prime} 08.1^{\prime \prime N}, 06^{\circ} 03^{\prime} 57.8^{\prime \prime W}, 2-I-2012: 2$ exx. Madrid: Brunete (Bolívar leg.): 2 exx.; Cadalso [de los Vidrios] (J. Ardois leg.): 120 exx.; Cadalso de los Vidrios, hacia Almorox, 12-IV-1992: 1 ex.; Cerro de San Pedro, 29-X-2004: 4 exx.; Collado Mediano (C. Bolívar leg.): 1 ex.; Collado Mediano: 13 exx.; Collado Mediano (G. Schramm leg.): 4 exx.; Collado Mediano (Moróder leg.): 5 exx.; Fresnedillas de la Oliva, $941 \mathrm{~m}, 40^{\circ} 29^{\prime} 38.57^{\prime \prime N}, 4^{\circ} 10^{\prime} 12.90^{\prime \prime W}, 14-I I I-2001$ : 14 exx.; Galapagar (Col. del Sr. Pérez Arcas) (Misolampus gibbulus Hbst.): 1 ex.; Manzanares [El Real], 30-III-1928: 1 ex.; Moralzarzal: Cerro del Telégrafo, 23-IV-2017: 1 ex.; Navas del Rey, 2-XII-1990: 2 exx.; Pelayos de la Presa, 799 m, 40²0'19.40"N, 4²1'34.84"W, 3-III2001: 1 ex.; [3 km al S de] Quijorna, 5-II-1992: 1 ex.; Robledo de Chavela: 7 exx.; Santa María de la Alameda (estación), 1-IV-1991: 10 exx.; Sierra de Guadarrama (J. Lauffer leg.): 1 ex.; Torrelodones, 7-XI-1992: 4 exx.; Valdemaqueda, 40³0'30.0"N, $4^{\circ} 17^{\prime} 00.1$ "W, 1-IV-2013: 2 exx.; Valdemorillo, 12-IV-1992: 7 exx.; Villa del Prado (J. Ardois leg.): 105 exx.; Villa del Prado: 4 exx.; Villa del Prado, Encinar del Alberche, 742 m, 40¹7'29.7"N, 04²21'11.9"W, 4-I-2009: 5 exx.; Villalba: 1 ex.

Diagnosis. Total length 6.6-12 mm (Reitter 1917; Español 1949; López-Pérez 2014a). Easily recognisable by its general shiny appearance and small size. Misolampus gibbulus presents acutely protruding prothoracic anterior angles, strong pronotal punctation, deep, and densely covering most of its surface; elytra with well-marked deeply excavated striae, with large and deep punctation, and shiny interstriae intervals often with additional series of punctures (Fig. 1A-D). Female genitalia figured by Palmer 
(1998). The species presents marked variability on the development and depth of the elytral and pronotal sculpture. Pronotal punctation is usually less developed, and elytral striae shallower, not so excavated, in populations of southwestern Portugal (Faro district) (see taxonomic discussion).

Geographic distribution. Endemic to Spain and Portugal (Löbl et al. 2008) (Fig. 2). Its general distribution includes most of the southwestern area of the Iberian Peninsula. Published records are however scanty, from central and southern Portugal, and from the Spanish provinces of Cáceres, Ciudad Real, Córdoba, Huelva, Jaén, Ma-

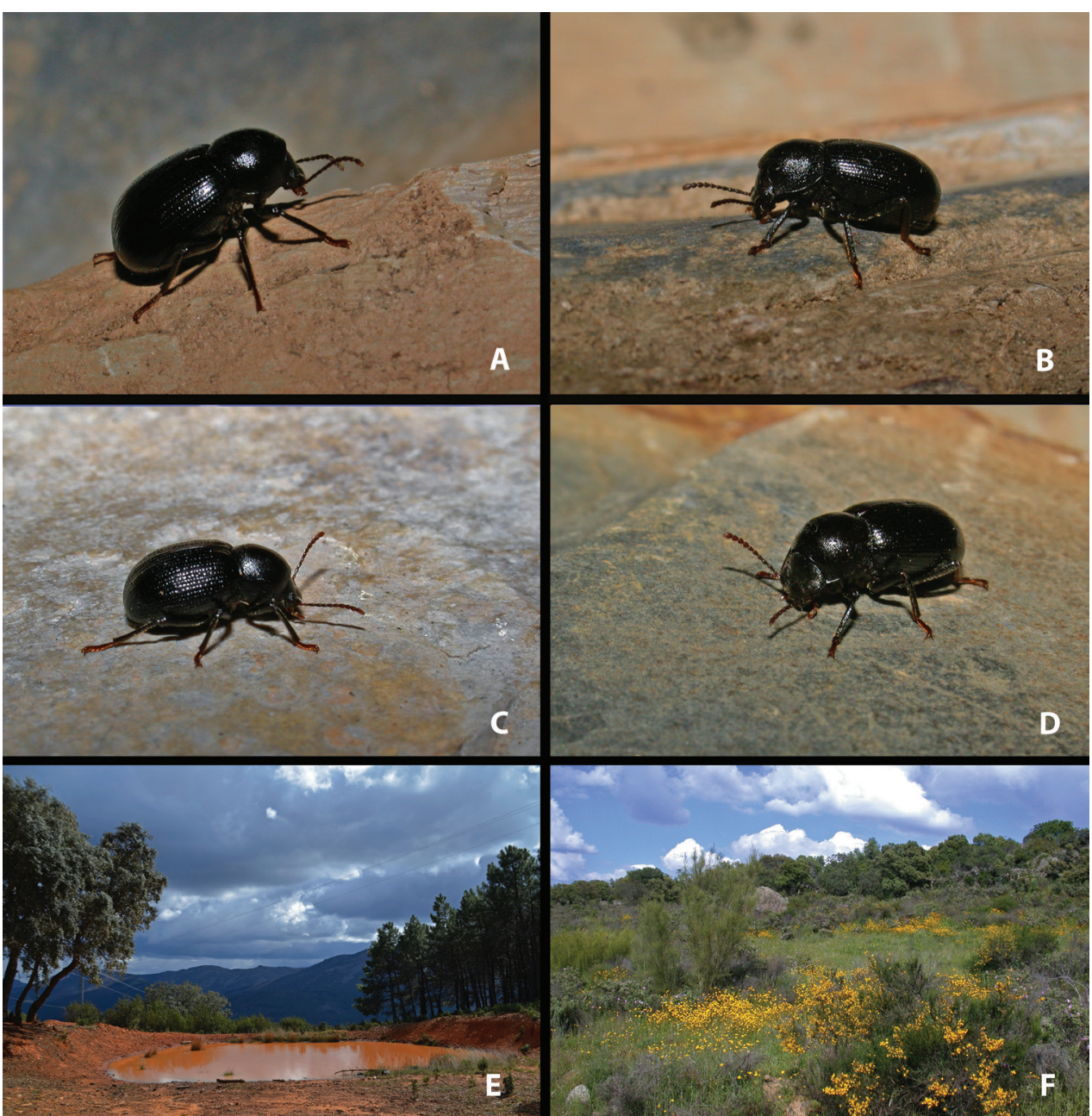

Figure I. Live specimens and habitat of Misolampus gibbulus A-D live adult specimens of Misolampus gibbulus from Portugal (A Foia; B Monchique; D São Martinho das Amoreiras) and Spain (C Santa Helena, Jaén); specimens $\mathbf{A}, \mathbf{B}$, and $\mathbf{D}$ represent the diversity of sculptural patterns in elytra and pronotum within the Faro population, see the contrast with typical specimen $\mathbf{C} ; \mathbf{E}, \mathbf{F}$ typical habitats of $M$. gibbulus in Spain (E native Quercus ilex and Pinus plantations at Robledo del Mazo, Toledo F Q. ilex open forest with Cytisus and Retama at Puerto de Santa Cruz, Cáceres). Photographs by MGP. 
A

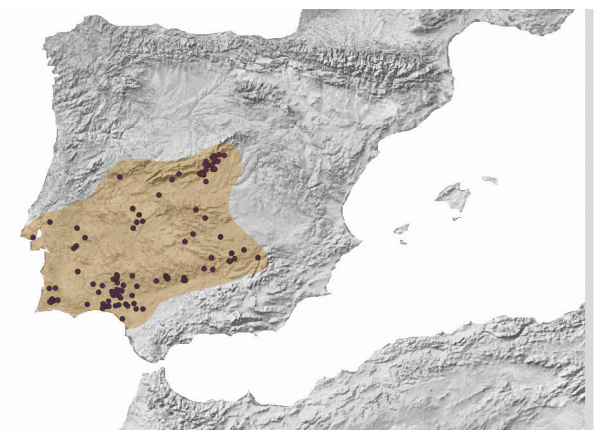

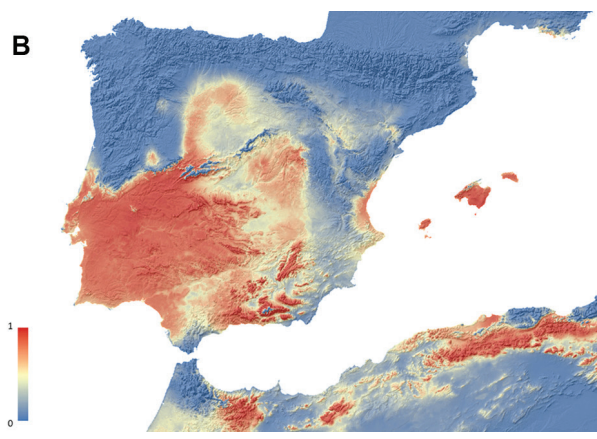

Figure 2. A Geographic distribution of Misolampus gibbulus. Map of the Iberian Peninsula depicting the geographic distribution range of the Iberian endemic Misolampus gibbulus (orange area). Purple dots correspond to the species' records, including both recent and old, as well as previously published data B potential geographic distribution of Misolampus gibbulus: Red indicates areas of high suitability, and blue, areas of low suitability. Species distribution model was generated using MaxEnt v 3.4.1 (Elith et al. 2006) and the set of WorldClim v 2.0 (Fick and Hijmans 2017) environmental variables.

drid and Sevilla (Latreille 1807; von Heyden 1870; Paulino de Oliveira 1894; Reitter 1917; Lindberg 1933; De la Fuente 1934-1935; Español 1949; Cabral 1983; Cárdenas Talaverón and Bujalance de Miguel 1985; Cárdenas 2003; Grimm and Aistleitner 2009; López-Pérez 2014a, 2014c; Bujalance de Miguel 2015; Barreda 2018).

Our new records considerably expand the known distribution of $M$. gibbulus. In addition to previously published data, we add new records for the district of Évora and Portalegre in Portugal, and from the provinces of Ávila, Badajoz, and Toledo in Spain; together with numerous localities for some provinces represented by a few records, such as Cáceres, Ciudad Real, and Madrid. With the addition of these records, the distribution of $M$. gibbulus seems to be more or less continuous along the southern slopes of the Sistema Central: from Cáceres and Ávila to Madrid, along both slopes of Montes de Toledo and Sierra Morena, and in a more or less extended area in southern Portugal, from Évora to Serra de Monchique in the Algarve region. The Guadalquivir river basin seems to conform the southeastern distribution limit for the species (Fig. 2A). The potential distribution map identifies southwestern Iberia as a high suitable area for the species occurrence, together with some areas where the species does not occur: the Betic Mountain ranges, the Balearic Islands, and northern Africa (Fig. 2B).

Notes on natural history. Misolampus gibbulus is a low altitude species, ranging from 4 to $1278 \mathrm{~m}$ a.s.l., although $81 \%$ of the populations recorded are located below $800 \mathrm{~m}$ of altitude. Geological substrates are very diverse across its distribution area, but mostly siliceous, including sandstones, gneisses, granites, and schists, which generate acid soils (see Vera 2004; Oliveira and Quesada 2019a, 2019b). It occupies mainly the meso-Mediterranean thermoclimatic belt and, to a lesser extent, the thermo - (at the southermost portion of its range) and supra-Mediterranean (on a narrow northern strip), with ombrotypes from dry to humid (Rivas-Martínez 1987; Rivas-Martínez et al. 2002; Rivas-Martínez 2007). It is found over an extensive variety of forest and subforestry habitats, including both coniferous (Pinus L.) and broadleaved trees (Quercus 
L., Fraxinus L.), and also dense shrublands of Cistus L. (“jarales"), Retama Raf. and Cytisus Desf. ("retamares") (Fig. 1E, F). The species also occupies areas densely reforested with native and non-native Pinus and Eucalyptus L'Hér. (Cabral 1983), as well as open man-modified agroforestry systems ("dehesas" of Quercus) and montane agrosystems with olive and chestnuts trees (Olea europaea L. and Castanea sativa Mill.) (see Ladero 1987; Rivas-Martínez et al. 1987; Valle 2003; Costa Tenorio et al. 2005).

Misolampus gibbulus is commonly found under bark or within decomposing dead logs and stumps of pines (mainly of Pinus pinea L. and Pinus sylvestris L.), including reforested areas (especially Pinus pinaster Aiton), where they appear to be particularly common. It is also found in dead or old trunks of perennial or deciduous oaks (Quercus ilex L., Quercus suber L., Quercus pyrenaica Willd. and Quercus faginea Lam.), under the dry layers that cover roots and thick stems of Cistus ladanifer L. and Cistus laurifolius L., and at the base of brooms, mainly Cytisus scoparius (L.) Link and Retama sphaerocarpa (L.) Boiss. Occasionally found under loose bark or at the base, among decaying wood of standing Eucalyptus trees, and also in rotten Eucalyptus stumps (Cabral 1983; López-Pérez 2014a; pers. obs.). Sometimes found also under stones in open areas, near forest or shrub patches. Almost all these habitat locations are coincident to those described by López-Pérez (2014a) for the province of Huelva. Its food source is unknown (as in the other species of the genus), although Barreda (2018) pointed out mistakenly that it is a moss eater (quoting Español 1949 and Bujalance de Miguel 2015); nevertheless, Español (1954b) commented that the species of Misolampus are saprophagous, without further specification.

Misolampus gibbulus has been found in microsympatry with M. scabricollis along western Sierra Morena (Huelva), northern Extremadura (Cáceres), Montes de Toledo (Toledo) (Fig. 1E), and southern slopes of the Sistema Central (Madrid, Ávila, Toledo), and with M. subglaber at the eastern end of Sierra Morena (Jaén) (pers. obs.). Adults can be found across most of the year (Cárdenas Talaverón and Bujalance de Miguel 1985; López-Pérez 2014a; Barreda 2018) but according to our observations they are more easily encountered during the wetter months (October to May).

\section{Misolampus goudotii Guérin-Méneville, 1834}

Misolampus goudotii Guérin-Méneville, 1834: 28. Terra typica: "trouvée à Tanger... ...à trois lieues de Tanger, sur les bords d'une rivière, dans le tronc d'un olivier." Vauloger de Beaupré (1900), Reitter (1917), Antoine (1949), and Español (1949) among others, wrote the species name with a single final -i. Solier (1848) and Vauloger de Beaupré (1900) mentioned the unavailable name: "Misolampus nigrita Dejean", and Español (1954a): "M. moraguesi".

Misolampus goudotii Erichson in Wagner, 1841: 184 (non Guérin-Méneville 1834). Terra typica: not indicated, but "von Algier" according to Erichson's (1841) work title. Misolampus erichsoni Vauloger de Beaupré, 1900: 674 syn. nov. Terra typica: "Algérie: O., Oran...; Daya...; Tlemcen...; Mascara..., Ammi Moussa; A.: Blidah...; La Chiffa...; Margueritte...; forêt de Boghar...; mont Ouarsenis...; forêts de la Grande-Kabylie...”. 
Misolampus peyerimhoffi Antoine, 1926: 257 syn. nov. Terra typica: "Grand Atlas, région du Glaoui: plateau des Aït Rba...”.

Studied material. Algeria: "Argelia" (Dufour leg.): 1 ex. MorocCo - MarrakechTensift-Al Hauz: Toufliht, 1483 m, 31²28'34.6"N, 7²6'06.5"W, 11-III-2013: 4 exx. - Meknès - Tafilalet: Ain Leuh, 17-V-1925: 1 ex.; Azrou, 1900 m (Alluaud 79) (Misolampus goudoti var. laevior Alluaud): 1 ex.; Azrou, 19-V-1925: 1 ex.; Dj. [Yebel] Hebri, 20-V-1925: 1 ex.; Timadit [Timahdite], 21-V-1923: 1 ex. - Tanger - Tétouan: Rif: Beni Siyyel: Bab Ruadi: VI-1932 (C. Bolívar leg.): 6 exx.; Tanger, 1897: 3 exx.; Tanger (M. Escalera leg.) (small square-label pinned): 36 exx., plus 3 exx. only squarelabelled; $2 \mathrm{~km}$ al O de Bab Berret, $1318 \mathrm{~m}, 35^{\circ} 00^{\prime} 02.57^{\prime \prime N}, 4^{\circ} 55^{\prime} 31.91^{\prime \prime W}, 12-\mathrm{VI}-$ 2011: 3 exx.; Crtra. Zinat-Mulay Abdeselam, P-4702, Beni Aros, Yebala, 513 m, 35'22'04"N, 532'17"W, 29-IV-2016: 5 exx.; Yebel Bou-Hachem, Beni Aros, Yebala, $1160 \mathrm{~m}, 35^{\circ} 15^{\prime} 31 " \mathrm{~N}, 5^{\circ} 30^{\prime} 49^{\prime \prime W}, 12-\mathrm{V}-2012$ : 6 exx.; Crtra. Mulay Abdeselam-Al Hamra, P-4704, Beni Aros, 985 m, 35¹5'50"N, 525'36"W, 28-XI-2019: 2 exx.; Larache: Yebala: Beni Arós: Yebel Bou-Hachem, 35¹5'31"N, 5³0'49"W, 9-VI-2012: 2 exx.; Pinsapar del Talassemtane, $1900 \mathrm{~m}, 35^{\circ} 08^{\prime} 36.7^{\prime \prime N}, 5^{\circ} 08^{\prime} 13.0^{\prime \prime} \mathrm{W}, 11-\mathrm{VI}-2011$ : 2 exx.; Bab Taza: Talassemtane, $1401 \mathrm{~m}, 35^{\circ} 06^{\prime} 10.9^{\prime \prime} \mathrm{N}, 5^{\circ} 08^{\prime} 21.3^{\prime \prime W}, 27-\mathrm{VII}-2013$ : 1 ex.; Bab Taza: Talassemtane: Plaza de España, 1667 m, 3509'03.7"N, 508'28.6"W, 27-VII-2013: 1 ex.; Casa Forestal, Yebel Lekraa, P.N. Talasemtane, Chefchaouen, 3507'56"N, 508'11"W, 1695 m, 7-VI-2008: 3 exx.; Yebel Talassemtane-vertiente sur, P.N. Talasemtane, Chefchaouen, $35^{\circ} 07^{\prime} 53^{\prime \prime} \mathrm{N}, 5^{\circ} 08^{\prime} 01 " \mathrm{~W}, 1650 \mathrm{~m}, 11-\mathrm{IV}-2011$ : 4 exx.; P.N. Yebel Tazaot, Pinsapar, P.N. Talasemtane, Chefchaouen, $35^{\circ} 15^{\prime} \mathrm{N}, 5^{\circ} 07^{\prime} \mathrm{W}$, 1670 m, 7-V-2011: 2 exx.; Pista hacia Casa Forestal, Yebel Lekraa, P.N. Talasemtane, Chefchaouen, 3507'45"N, 508'09"W, 1700 m, 28-VII-2011: 1 ex.; E. de Yebel Talaousisse, P.N. Talasemtane, Chefchaouen, $35^{\circ} 07^{\prime} 33^{\prime \prime N}, 5^{\circ} 04^{\prime} 03^{\prime \prime W}, 1350 \mathrm{~m}, 1-\mathrm{XII}-$ 2018: 2 exx.; Pista hacia Haout Taznout, P.N. Talasemtane, Chefchaouen, $35^{\circ} 08^{\prime} 20^{\prime \prime N}$, 507'24"W, 1712 m, 27-IV-2019: 2 exx.; Yebel Tizirhen, Bab Berred, Rif Central, 1585 m, 3500'54"N, 4º 54'57"W, 27-IV-2017: 3 exx.; Yebel Tizirhen, Bab Berred, Rif Central, 1570 m, 3500'47"N, 454'03"W, 28-IV-2018: 1 ex.; Pista de Bab El Kar, Montañas de Fifi, Rif, 1512 m, 34059'13"N, 5¹1'20"W, 2-VI-2019: 2 exx. - Taza Al Hoceima - Taounate: Iguermalen [Targuist]: Beni Mesdui, VI-1932 (M. Escalera leg.): 6 exx.; Rif: Beni Seddat: Imosiner: VI-1930 (exp. C. Bolívar leg.): 3 exx.; Rif: Beni Seddat: Tizi Taka, VI-1932 (C. Bolívar leg.): 4 exx.; Rif: Beni Seddat: Tizi Taka, VI-1932 (Exp. C. Bolívar leg.): 1 ex.; Rif: Iguermalen (Targuist), VI-1930 (exp. C. Bolívar leg.): 4 exx.; Rif: Ketama, Bab Chiquer, VI-1932 (C. Bolívar leg.): 8 exx.; Rif: Ketama, Bab Chiquer, VI-1932 (M. Escalera leg.): 2 exx.; Rif: Ketama: Tainza, VI1930 (exp. C. Bolívar leg): 3 exx.; Rif: Ketama: Tidiguin [Tidghine], VI-1930 (exp. C. Bolívar leg.): 1 ex.; Rif: Ketama: Zoco Telata, VI-1932 (M. Escalera leg.): 7 exx.; Lurdeka [?]: 1 ex.; Yebel Tidighin, Azila, Rif central, 1705 m, 3451'14"N, 4³2'19"W, 29-XI-2019: 1 ex; Carretera P-5420, P.N. Tazzeka, Medio Atlas nororiental, 1000 m, $34^{\circ} 03^{\prime} \mathrm{N}, 4^{\circ} 15^{\prime} \mathrm{W}, 25-\mathrm{XI}-2004$ (F.J. Martínez leg.): 2 exx. - Souss-Massa-Drâa: Yebel Tual, 28-VII-1934: 1 ex.; Ifni: Yebel Tamarrut [25 km SE Ifni], I-1935 (F. Escalera 
leg.): 1 ex.; Sidi Ifni: Akarkor, Jbel Toual, 627 m, 29¹3'48.9"N, 1000'44.1"W, 21-I-2020: 4 exx. Spain - Islas Baleares: Mallorca (Mas de Xaxars leg.) (Misolampus erichsoni): 2 exx.; Escorca, 26-III-1985, 1 ex.; Escorca, Coll de Femenia, 545 m, 3951'33.68"N, 254'19.27"W, 25-III-2012: 10 exx.; Menorca (Cardona leg.): 2 exx. plus 6 exx. without data; 2 exx.; Menorca: 2 exx.; Algaiarens, $14 \mathrm{~m}, 40^{\circ} 02^{\prime} 28.3^{\prime \prime} \mathrm{N}$, 035'28.4"W, 27-IV-2006: 2 exx.

Diagnosis. With a total length from 10 to $14 \mathrm{~mm}$, this is the largest species of the genus (Vauloger de Beaupré 1900; Reitter 1917; Antoine 1926; Español 1949). This species is well characterised and isolated within the genus Misolampus by the following traits: fore angles of the prothorax not protruding, almost rounded, forming an obtuse angle at apex; lateral surface of pronotum shallowly rugose, with the rugosity progressively erased towards the dorsal areas that appear smoother, propleural punctation fine and often erased; elytra with longitudinal series of small elongated tubercles, more apparent on the sides of the posterior half of the elytra (Español 1949, 1954a; Palmer 1998) (Fig. 3A-C). Female genitalia figured by Palmer (1998). Specimens from the Balearic Islands have been studied karyologically (Juan and Petipierre 1986, 1989; Juan et al. 1993; Pons et al. 1993; Pons 2004), presenting a chromosome number of 20 (2n) (Juan and Petitpierre 1986, 1989). There is marked geographical variability on the sculpture and shape of pronotum and propleurae, and on the development of elytral tubercles (Vauloger de Beaupré 1900; Antoine 1949; Español 1954a) (Fig. 3A-C). Specimens from northern Morocco (excluding the Tingitane Peninsula), Algeria and the Balearic Islands, present a well-developed and evident elytral tuberculation that may form rugose ridges (Fig. 3A). On the other extreme, elytral tubercles are reduced in the Rif and Atlas populations (Fig. 3B), to become almost completely absent in the specimens from Sidi Ifni (Fig. 3C). Pronotum sculpture is formed by fine spaced punctures intermixed with granules, much denser on the sides in the Balearic Islands population (Fig. 3A); pronotal rugose areas are more marked and extended in the specimens from the High Atlas (Fig. 3B), and formed by sparse punctation, without granulose areas, in the specimens from Ifni (Fig. 3C). The anterior edge of the pronotum, in the Rif and Balearic populations, is straight at the middle, while it appears convex in the populations from the High Atlas (Antoine 1949). The geographic distribution of this variability has been the subject of taxonomic discussion resulting in the proposal of different taxa, here formally synonymised (see synonymic list, and taxonomic discussion).

Geographic distribution. Distributed throughout Morocco, northern Algeria and the Balearic Islands in Spain (Antoine 1926, 1949; Español 1949; Löbl et al. 2008). Precise records are well distributed in northern Morocco and Mallorca, scanty in all other areas (Solier 1848; Lucas 1849; Cardona Orfila 1872; Pérez Arcas 1873; Moragues 1889; Champion 1891; Vauloger de Beaupré 1900; Martínez de la Escalera 1914; Reitter 1917; Peyerimhoff 1919; Antoine 1926; Lindberg 1933; De la Fuente 1934-1935; Palau 1945; Antoine 1949; Español 1949, 1953, 1954a; Cobos 1955; Pardo Alcaide 1955; Kocher 1958; Cobos 1961; Español 1967; Mouna and Arahou 1986; Juan and Petitpierre 1989; Whitehead 1993; París García et al. 2011; Benyahia et al. 2015, 2016; Núnez et al. 2016; Chavanon 2020) (Fig. 4). The record from Ceu- 


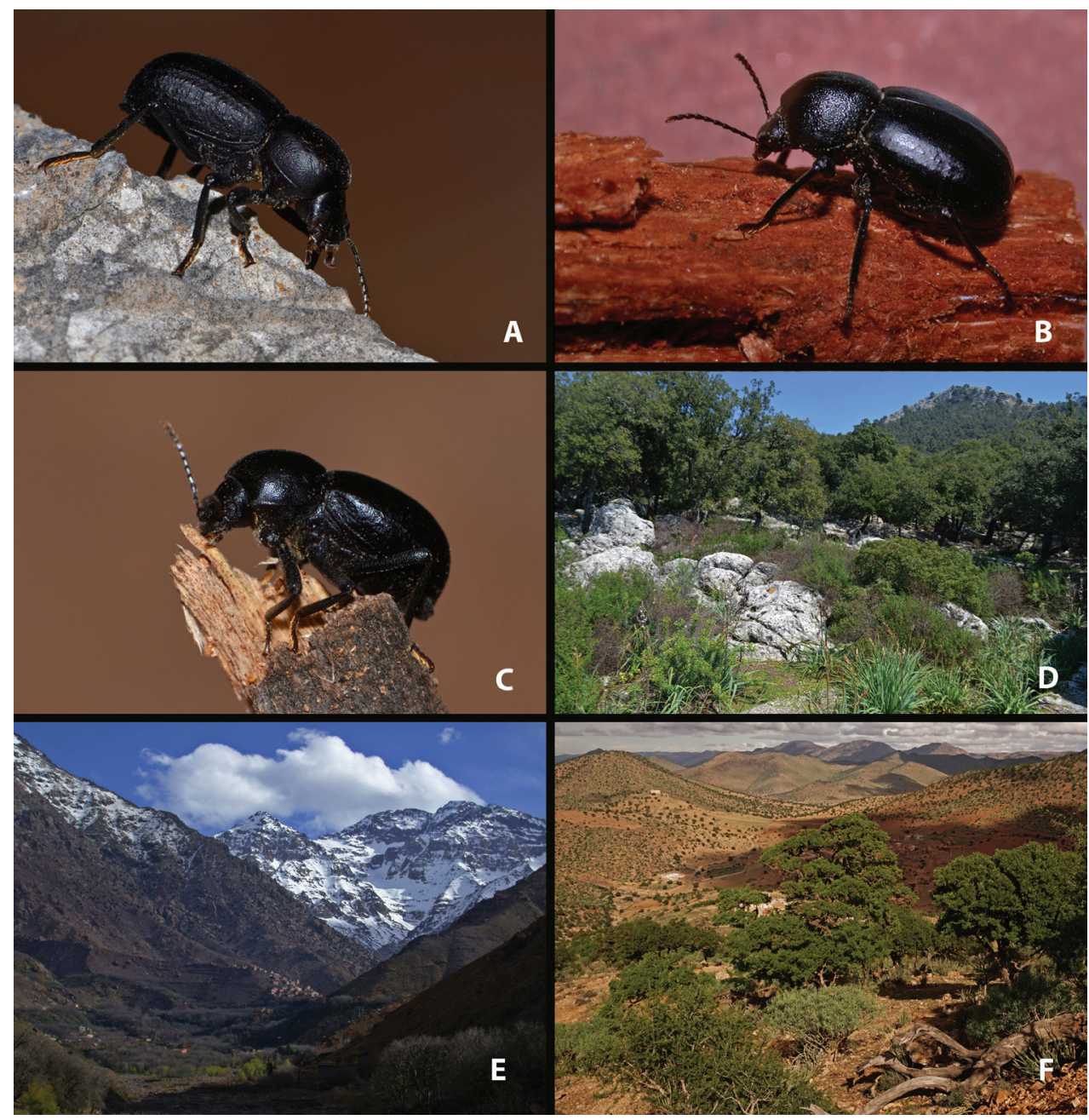

Figure 3. Live specimens and habitat of Misolampus goudotii A-C Live adult specimens of Misolampus goudotii from the Balearic Islands (A Cap Formentor, Mallorca) and Morocco (B Toufliht, High Atlas C Akarkor, Sidi Ifni); the specimens selected represent the diversity of sculptural patterns in elytra and pronotum reported for the species D-F A summary of the impressive habitat diversity used by M. goudotii from the Balearic Islands (D Quercus ilex forest at Creu de Menut, Mallorca), to southwestern Morocco (E deep valleys in the Toubkal National Park, High Atlas F Argania spinosa open forests at Jbel Toual in Sidi Ifni). Photographs by MGP and NRR.

ta, Spain (Vauloger de Beaupré 1900) corresponds to the mountain Yebel Musa (just $1.5 \mathrm{~km}$ west of Ceuta), currently in Moroccan territory (region of Tanger-Tétouan).

The studied materials include recent and old records of populations from the Balearic Islands (Mallorca and Menorca) and from the Moroccan regions of Meknès-Tafilalet, Souss-Massa-Drâa, Tanger-Tétouan, and Taza-Al Hoceima-Taounate. Recent data are available from all four regions, with a large number of localities from the Rif, and less numerous in the Middle and High Atlas. Among these records, we emphasise the re-dis- 
covery of the population from the province of Sidi Ifni, in January-2020, 85 years after its original finding, by F. Martínez de la Escalera in 1934 and 1935 (París García et al. 2011). The latter is a singular population, apparently isolated in the arid mountains near Ifni; its closest known population is located in the Western High Atlas, ca. $250 \mathrm{~km}$ to the northeast (Fig. 4A). The potential distribution map locates high suitable areas for this species along the mountain ranges of northwestern Africa, the coastal and mountain areas in the Tingitane peninsula, and along the coast of Rabat-Salé-Kénitra region. It also identifies areas where the species does not occur as high suitable, including sothwestern Iberia, the Balearic Islands and Sardinia. The Ifni population is located in a very fragmented area of high suitability, suggesting a possible Pleistocene relict status for this population (Fig. 4B).

Notes on natural history. Misolampus goudotii is widely distributed over northwestern Africa, though restricted to mountain ranges and adjacent areas: Rif, Middle Atlas, western High Atlas, Beni Snassen mountains, southwestern foothills of the AntiAtlas (Morocco) and Tellian Atlas (Algerie) (Fig. 4). Altitudinal range in the Maghreb from 2 to $2064 \mathrm{~m}$ a.s.1., with $70.5 \%$ of records above $800 \mathrm{~m}$ of altitude $(62 \%$ above $1000 \mathrm{~m}$ ). In the Balearic Islands its altitudinal range is lower, between 15 and $718 \mathrm{~m}$ a.s.l., but the species is found mainly in areas of mountainous topography (e.g., Serra de Tramuntana in Mallorca). It inhabits a wide range of geological substrates, both acid and basic, from plutonic and metamorphic types to calcareous and dolomitic rocks (see Michard 1976; Vera 2004; Oliveira and Quesada 2019a, 2019b). Misolampus goudotii is a euryecious species that occurs at infra-, thermo-, meso- and supraMediterranean thermoclimatic belts, in regions with ombrotypes from arid to hyperhumid (Benabid 1985; Rivas-Martínez 1987; Le Houerou 1989; Rivas-Martínez et al. 2002; Rivas-Martínez 2007; Sebbar et al. 2013), and occupies a wide variety of forest formations, both coniferous [Tetraclinis articulata (Vahl) Mast., Abies maroccana Trab., Cedrus atlantica (Endl.) Manetti ex Carrière, Juniperus phoenicea L., Juniperus thurifera L., Pinus nigra J.F. Arnold, Pinus halepensis Mill., P. pinaster] and broadleaved [deciduous: Quercus canariensis Willd., Quercus afares Pomel, Q. faginea, Q. pyrenaica; perennial: Quercus ilex, Q. suber, Olea europaea var. sylvestris (Mill.) Lehr] (see Benabid 1982, 1984, 1985; Benabid and Fennane 1994; Bolòs 1997; Charco 1999; Benabid 2000; Taleb and Fennane 2019). It also occurs in areas reforested with pines (pers. obs.) (Fig. 3D, E). The population of Ifni inhabits mountains (620-1225 m of altitude) at the infra-Mediterranean thermoclimatic belt, probably affected by the proximity to the Atlantic Ocean and consequently by the presence of some degree of cryptic precipitation (Géhu and Biondi 1998). The vegetation of the area is dominated by open forest of Argania spinosa (L.) Skeels, with sparse cactiform and arbustive Euphorbia L. (Médail and Quézel 1999; Ruiz and García-París 2015), and large areas covered by formerly cultivated Opuntia Mill (Fig. 3F).

In the Moroccan Rif, $M$. goudotii is often encountered under bark, inside fallen logs or stumps, and at the base of dead old oaks (perennial: Q. ilex, Q. suber; deciduous: Q. canariensis, Q. faginea and Q. pyrenaica), arbutus trees (Arbutus unedo L.), wild olive trees (O. europaea var. sylvestris), pines ( $P$. nigra, $P$. pinaster, $P$. halepensis), firs (Abies maroccana), and cedars (Cedrus atlantica), as already reported partially by Vauloger de Beaupré (1900), Cobos (1955, 1961), and Benyahia et al. (2015, 2016). 
A

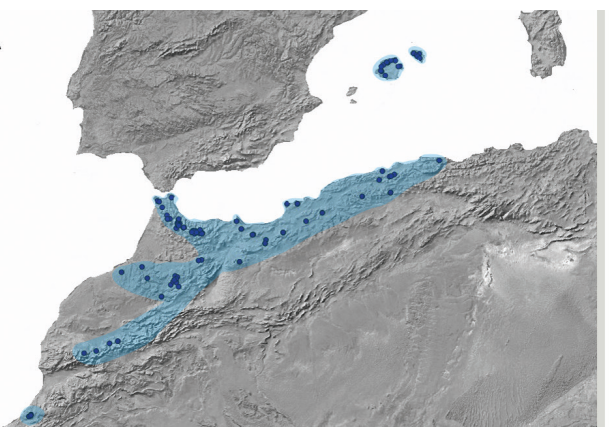

B

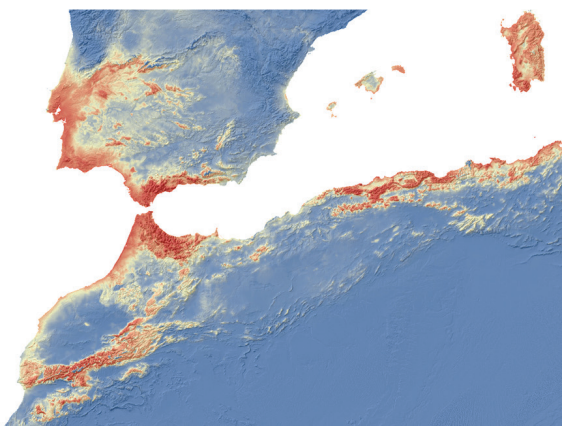

Figure 4. A Geographic distribution of Misolampus goudotii. Map for the distribution range of Misolampus goudotii (pale blue spot). Blue dots correspond to the species records, including both recent and old, as well as previously published data. The population from Ifni remains isolated from the main distribution range, by a distance of ca. $250 \mathrm{~km}$ B potential geographic distribution of Misolampus goudotii: Red indicates high suitable areas, and blue, areas of low suitability. Species distribution model was generated using MaxEnt v 3.4.1 (Elith et al. 2006) and the set of WorldClim v 2.0 (Fick and Hijmans 2017) environmental variables.

They can also be found under bark of standing dead trees (A. maroccana, C. atlantica, Q. suber, Q. pyrenaica). In the Middle and High Atlas, it is usually found under bark and inside large decaying logs of Q. ilex (Antoine 1926), but also in old decomposing logs of P. nigra and C. atlantica. Mouna and Arahou (1986) collected the species on thuya (Tetraclinis articulata) in the Korifla Valley (northwestern Morocco). Sidi Ifni specimens were found within crevices in old dead logs of Argania spinosa, almost buried on the ground of a steep slope (Fig. 3F). Nearby standing dead trunks were occupied by Nesotes tuberculipennis villarubiai (Español, 1943) as described by Nabozhenko (2015). In Algeria, they have been found under bark of fallen pines (Vauloger de Beaupré 1900). In Menorca, it has been found in oak forests of Q. ilex, under bark or under stones and leaf litter (Cardona Orfila 1875), and in Mallorca it is frequent in decaying wood of fallen pines (P. pinea) and old oaks (Q. ilex) (Fig. 3D).

Adult specimens are often found in aggregations. We found aggregations of approximately 15 specimens close together in a single large rotting pine log in Mallorca. We also found aggregations of M. goudotii together with Helops insignis maroccanus (Fairmaire, 1873) (Tenebrionidae, Helopinae) under bark of dead trees of Q. suber, A. maroccana and C. atlantica in the Rif Mountains. Whitehead (1993) relates the finding on two occasions of groups of individuals between the annual rings of dead pines ( $P$. halepensis) in active colonies of ants of the genus Messor Forel, 1890 and of the species Monomorium bicolor Emery, 1877 (probably another species of Monomorium Mayr, 1855, since the invasive M. bicolor is not present in Balearic Islands; Salata et al. 2019).

Adults are present all year round, but they are more commonly seen in winter and spring in middle and low elevations (Vauloger de Beaupré 1900; Español 1967; pers. obs.), and in summer at higher altitude (Antoine 1926), however, Moragues (1889) mentioned collections during the summer in Mallorca. 


\section{Misolampus lusitanicus Brême, 1842}

Misolampus lusitanicus Brême, 1842: 82. Terra typica: "Portugal".

Studied material. Portugal - Porto: Fervença - Eido, 585 m, 41ํํ' $28.98^{\prime \prime N}$, 757'00.34"W, 24-IV-2012: 23 exx. Spain - Castilla y León: León: Lago de la Baña, $1418 \mathrm{~m}, 4^{\circ} 15^{\prime} 23.2^{\prime \prime N}, 6^{\circ} 44^{\prime} 58.6 \mathrm{WW}, 22-\mathrm{VIII}-2016: 1$ ex. - Galicia: Ourense: Fumaces, $804 \mathrm{~m}, 41^{\circ} 56^{\prime} 50.2^{\prime \prime N}, 7^{\circ} 21^{\prime} 05.7^{\prime \prime W}, 20-X I-2012: 3$ exx.; Sierra de Oneija [Queixa] (A. Kricheldorff leg.): 1 ex.

Diagnosis. Total length $7.5-8.0 \mathrm{~mm}$, one of the smaller species within the genus (Reitter 1917; Español 1949; pers. obs.). Antennae relatively short, not reaching the base of prothorax (Español 1949). Pronotum with relatively deep, dense, well-defined punctation covering all its surface. Elytra covered by dense punctation somewhat confused with shallow granulation, or partially erased at the disc (Fig. 5A-D). Female genitalia figured by Palmer (1998). We have not observed any relevant morphological variability among the populations studied.

Geographic distribution. Endemism of northern Portugal and northwestern Spain (Löbl et al. 2008) (Fig. 6). Published records are very scarce but distributed in the district of Braga (Portugal) and provinces of León, Ourense, Pontevedra, and Zamora (Spain) (Brême 1842; von Heyden 1870; Paulino de Oliveira 1894; Reitter 1917; De la Fuente 1934-1935; Español 1949, 1955, 1956; Español and Comas 1981; Novoa et al. 2014).

The material we studied includes recent representation from the provinces of León and Ourense in Spain, and from the Porto district in Portugal. To date, the species is only known from ten localities (Fig. 6A). The potential distribution map locates high suitable areas for this species mainly in the northwestern region of the Iberian Peninsula (Fig. 6B).

Notes on natural history. Misolampus lusitanicus is a medium altitude species (altitudinal range 572-1680 m a.s.l.; 59\% of records above $1000 \mathrm{~m}$ ), typical of mountainous reliefs of northwestern Iberian Peninsula (Macizo Galaico-Leonés mountain range: Serra San Mamede-Queixa, Serra do Eixe, Serra do Gêres, Serra Segundeira y do Porto, Serra dos Ancares, Serras Occidentais and Montes de León). Geological substrates in its geographic range are mainly granite, gneiss and, to a lesser extent, quartzite, which form acid soils (Vera 2004; Oliveira and Quesada 2019a, b). It occupies meso- and supra-Temperate thermoclimatic belts, and more locally meso- and supra-Mediterranean, mostly in the Atlantic European biogeographic province, in high rainfall regions, with ombrotypes humid and hyperhumid (Rivas-Martínez 1987; Rivas-Martínez et al. 2002; Rivas-Martínez 2007). The species inhabits humid forest habitats, mainly of deciduous oak trees (Quercus robur L., Q. pyrenaica), hazel (Corylus avellana L.), birch (Betula pubescens ssp. celtiberica Rothm. \& Vasc.), chestnut trees (Castanea sativa), and yews (Taxus baccata L.), but also heathlands and rocky open areas covered by broom shrubs (Cytisus oromediterraneus Rivas Mart. \& al. and C. scoparius) (see Izco 1987; Rivas-Martínez 1987; Costa Tenorio et al. 2005) (Fig. 5E, F). 


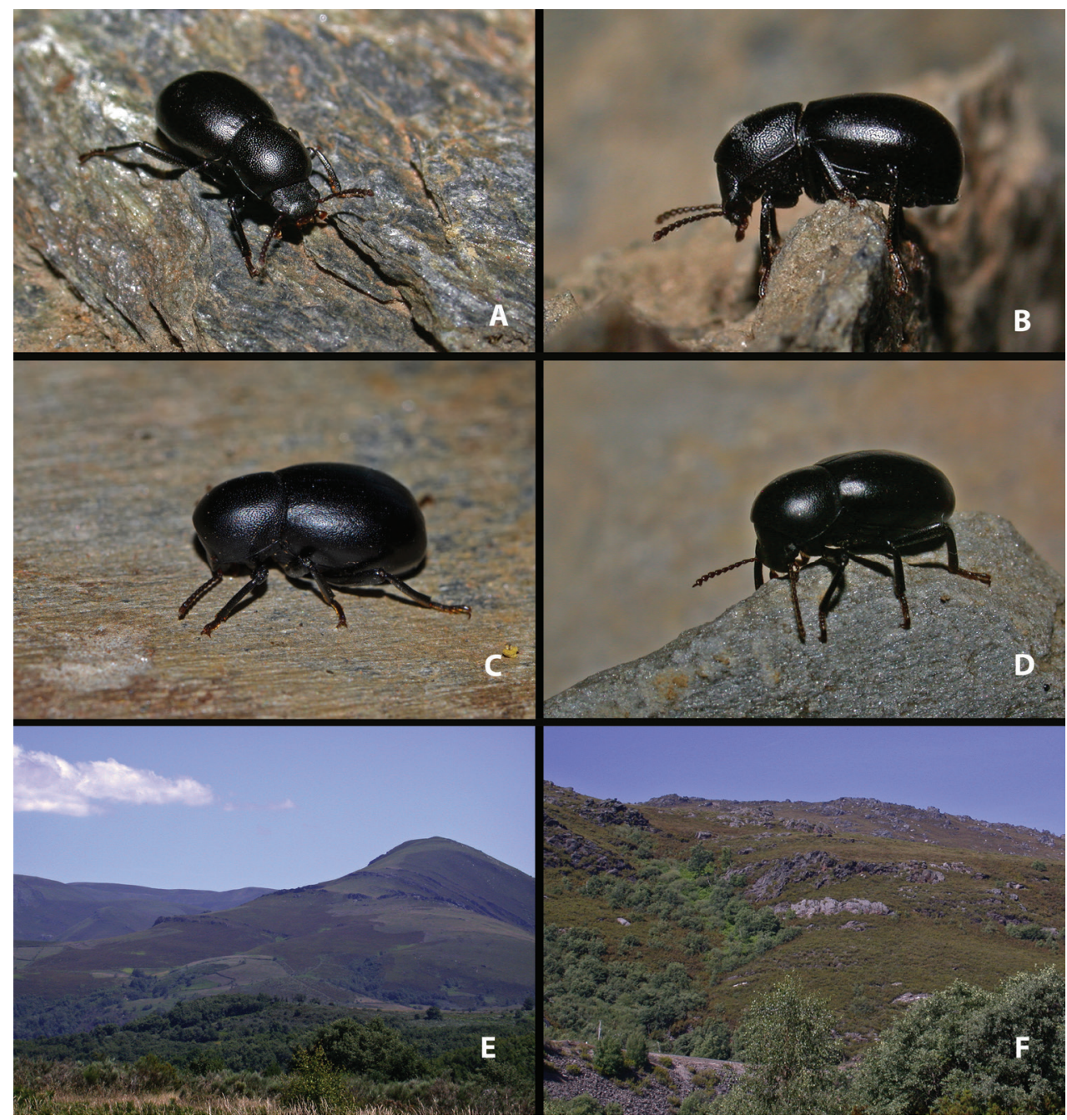

Figure 5. Live specimens and habitat of Misolampus lusitanicus A-D live specimens of Misolampus lusitanicus from Spain (A, B Fumaces, Ourense C Laguna de La Baña, León) and Portugal (D Fervença-Eido, Porto) E, $\mathbf{F}$ two examples of typical habitat of $M$. lusitanicus from E Sierra de Queixa (Ourense) and F Mountains of Sanabria (Zamora). Photographs by MGP.

Adults are usually found at the base of trees, under bark, under stones or in leaf litter of forests (Español 1956; Español and Comas 1981), but also under stones in mountain shrub-lands (pers. obs.). It has also been found in densely reforested areas with $P$. pinaster, and also in chestnut groves (C. sativa). It has not been recorded in sympatry with any other species of Misolampus, but it has been found in company of Coelometopus clypeatus (Germar, 1813) (Tenebrionidae, Cnodalonini) (Español and Comas 1981). According to the limited available data, adults seem to be present all year round. 
A

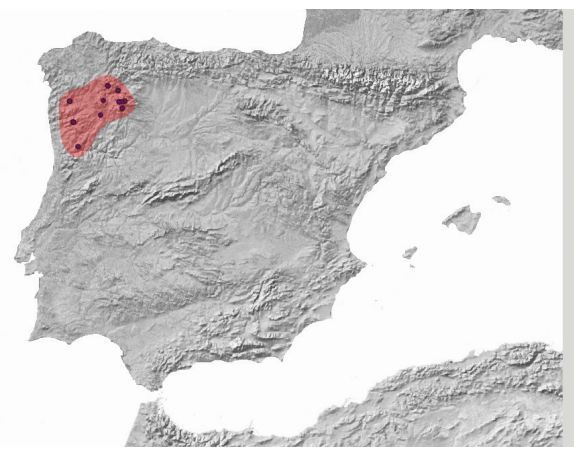

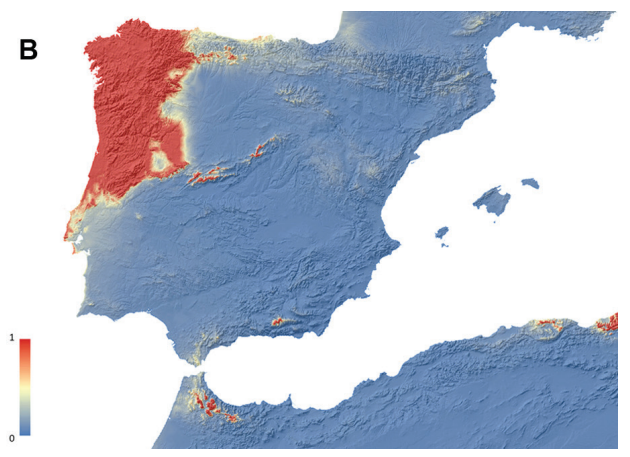

Figure 6. A Geographic distribution of Misolampus lusitanicus. Map depicting the distribution range of the Iberian endemic Misolampus lusitanicus (red spot). Purple dots correspond to the species records, including both recent and old, as well as previously published data $\mathbf{B}$ potential geographic distribution of Misolampus lusitanicus: Red indicates areas of high suitability, and blue, areas of low suitability. Species distribution model was generated using MaxEnt v 3.4.1 (Elith et al., 2006) and the set of WorldClim v 2.0 (Fick and Hijmans 2017) environmental variables.

\section{Misolampus ramburii Brême, 1842}

Misolampus ramburii Brême, 1842: 82. Terra typica: "De l'Espagne meridionale". Some authors wrote the species name with a single final -i (Rosenhauer 1856; Paulino de Oliveira 1894; Reitter 1917; De la Fuente 1934-1935; Palau 1945; Español 1949).

Studied material. SPAIN - Andalucía: Almería: Fondón: 2 exx.; Sierra Bacares: 1900 (Escalera leg.): 3 exx.; Sierra Alhamilla, Almería, 1240 m, 36 $59^{\circ} 25^{\prime \prime N}, 02^{\circ} 20^{\prime} 13^{\prime \prime W}$, 30-XII-2003 (P. Barranco leg.): 1 ex.; Sierra de Gádor, 892 m, 36 55'32.18"N, 2³5'57.07"W, 27-III-2012: 3 exx.; Granada: Jayena, 30-VII-1920: 4 exx.; Puerto de la Mora, $1294 \mathrm{~m}, 37^{\circ} 15^{\prime} 19.71 " \mathrm{~N}, 3^{\circ} 29^{\prime} 01.80^{\prime \prime W}, 26-\mathrm{III}-2012$ : 2 exx.; Pista La Alcaicería-El Robledal (encinar), Sierra Tejeda, 1020 m, 36 $57^{\prime} 07^{\prime \prime N}, 4^{\circ} 00^{\prime} 56^{\prime \prime W}, 5-I-$ 2005: 1 ex.; Málaga: Málaga (Aragoncillo leg.) (Col. del Sr. Pérez Arcas): 1 exx.; Arroyo Güi, Torrox, 155 m, 3646'36"N, 359'29"W, 23-XII-2000: 4 exx.; Lagos, Velez-Málaga, 102 m, 364 $45^{\prime} 00^{\prime \prime N}, 4^{\circ} 00^{\prime} 28^{\prime \prime W}, 15-I V-2006: 2$ exx.; Área El Pinarillo, Nerja, Sierra de Almijara, 485 m, 3647'53"N, 350'55"W, 3-I-2003: 6 exx.; Área El Pinarillo, Nerja, Sierra de Almijara, 471 m, 3647'52"N, 350'58"W, 4-I-2012: 3 exx.; Cerro El Cañuelo, Acantilados de Maro-Cerro Gordo, Nerja, 130 m, 36 44'57"N, 347'12"W, 29-XII-2007: 1 ex.; Carril Cuevas de Nerja-El Pinarillo, Sierra de Almijara, 340 m, 36 $46^{\prime} 58^{\prime \prime} \mathrm{N}, 3^{\circ} 50^{\prime} 24 " \mathrm{~W}, 30-\mathrm{III}-2018: 2$ exx.; Alrededores Cuevas de Nerja, Maro, Nerja, 171 m, 36 $45^{\prime} 46 " N, 3^{\circ} 50^{\prime} 43^{\prime \prime W}, 2-X I-2018: 1$ ex. - Murcia: Sierra Espuña: VIII-1943 (G. Menor leg.): 1 exx.

Diagnosis. Total length 9-11 mm (Reitter 1917; Español 1949). Misolampus ramburii is characterised by its shiny appearance and by presenting the anterior 
angles of prothorax slightly protruding forward. Pronotal punctation deep and dense, not as strong as in $M$. gibbulus, without granular areas. Elytra with shallow striae formed by series of punctures in longitudinal series, sometimes almost absent (Fig. 7A, B). Elytral inter-striae smooth. Female genitalia figured by Palmer (1998) and aedeagus by Español (1949). Adults present a marked variability in elytral sculpturing, smoother with elytral striae almost erased in the western populations of Sierra de Almijara and Sierra de Huétor (Fig. 7B); more marked in the eastern areas (Fig. 7A) (see taxonomic discussion).

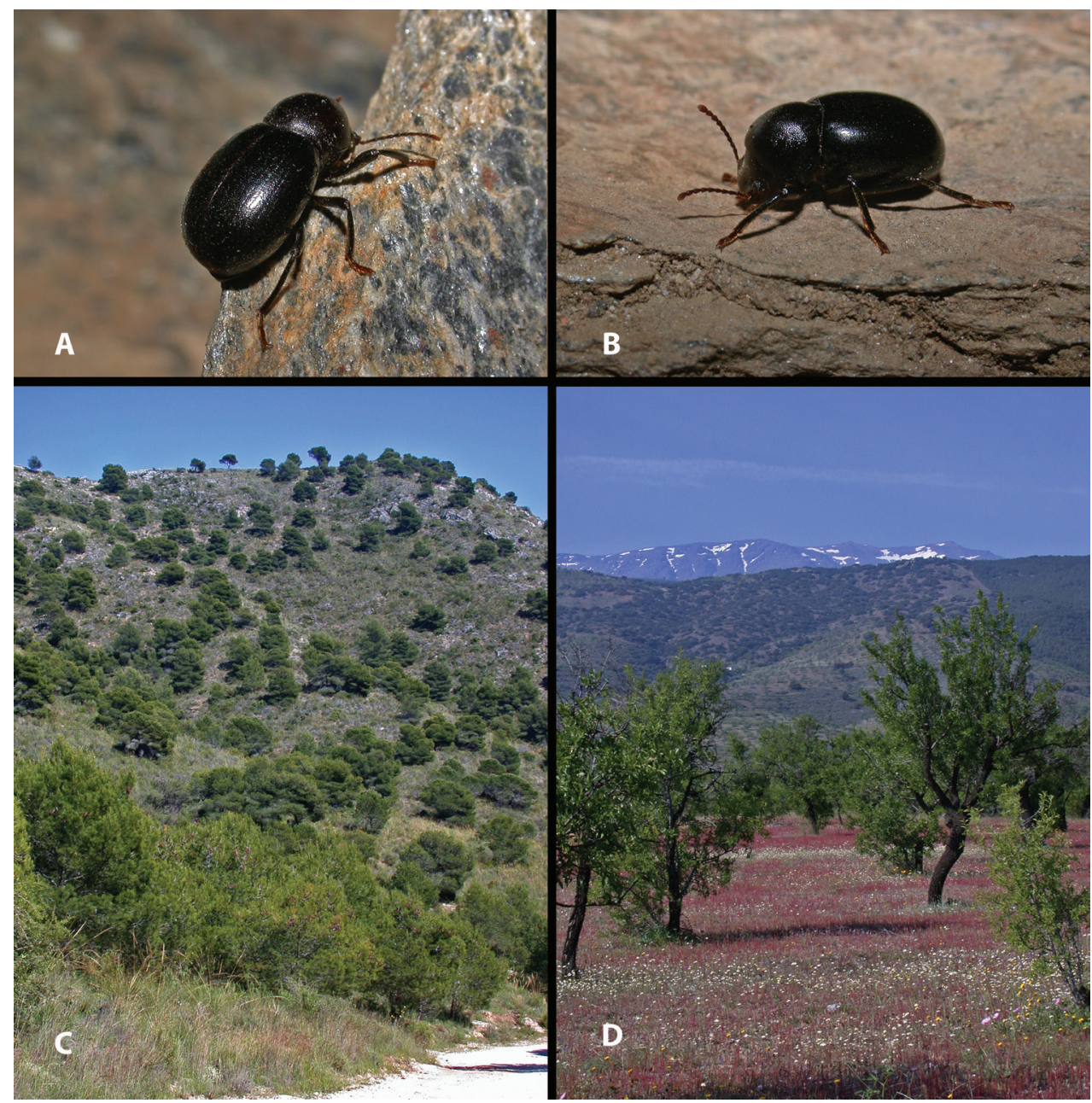

Figure 7. Live specimens and habitat of Misolampus ramburii A, B adult Misolampus ramburii from Spain (A Sierra de Gádor, Almería B Sierra de Huétor, Granada); the specimens selected represent the diversity of sculptural patterns in elytra and pronotum, smoother in western populations, without elytral striae (B), marked in eastern areas (A) C, D two examples of typical habitat of $M$. ramburii from C coastal ravines with scattered Pinus halepensis (Maro, Málaga) and D slope of Sierra Nevada with open forests of $Q$. ilex and almond trees (Almería). Photographs by MGP. 
Geographic distribution. Endemism of southeastern Spain and Mallorca in the Balearic Islands (Fig. 8). Records from Portugal, as Serra de Monchique (Paulino de Oliveira 1894; Reitter 1917; Löbl et al. 2008), are based on misidentifications (see taxonomic discussion). Published records are scarce, but covering most of the known species range, from the provinces of Almería, Granada, Málaga, Murcia, and the island of Mallorca (Rosenhauer 1856; von Heyden 1884 sub M. scabricollis; Reitter 1917; De la Fuente 1934-1935; Palau 1945; Cobos 1949; Español 1949, 1954a, 1954b, 1963; SánchezPiñero et al. 2013; Valladares et al. 2013). All published records are relatively old, except those from Almería and Granada. According to the current records, M. ramburii is restricted to the Betic Mountain ranges (Montes de Málaga, Sierra Nevada, Sierra de Huétor, Sierras de Tejeda and Almijara, Sierra de Filabres, Sierra de Gádor, Sierra Alhamilla, Sierra Espuña), and in Malllorca to the southwestern foothills of the Sierra de Tramuntana, including Palma Bay (Fig. 8A). The record of an unidentified Misolampus from Sierra de Contraviesa (Granada) (Español 1963), found in the company of Coelometopus cobosi Español, 1963, probably corresponds to $M$. ramburii (see taxonomic discussion).

Materials studied by us include specimens from all previously reported areas except Mallorca (not searched for). Records are recent for all localities except for those from the Murcia region (Sierra Espuña). The potential distribution map (Fig. 8B) shows that highly suitable areas are primarily located in the coasts and mountain ranges of the south of Almería, Granada, and Málaga and the northwest of Mallorca island, coinciding with the recorded presence of the species. The northwestern coast of the Iberian Peninsula and the mountain ranges of Northwestern Africa are also pointed as areas of high suitability.

Notes on natural history. Misolampus ramburii is a low-medium mountain species, even sub-coastal, with an altitudinal range between 14 and $1673 \mathrm{~m}$ a.s.l. (60\% of records below $1000 \mathrm{~m}$ of altitude); in Mallorca it is also found at low altitude, 14-398 m a.s.l. Lithological substrates of its area of occupancy are very diverse, due to the high
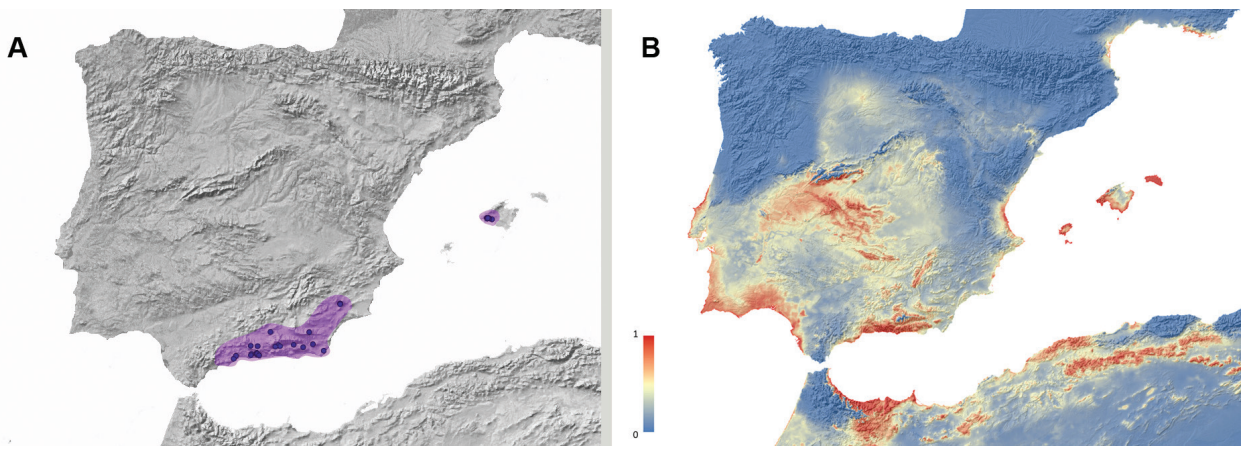

Figure 8. A Geographic distribution of Misolampus ramburii. Map of the Iberian Peninsula depicting the geographic distribution of Misolampus ramburii (purple spot), an endemic species to Spain. Blue dots correspond to the species records, including both recent and old, as well as previously published data B potential geographic distribution of Misolampus ramburii: Red indicates areas of high suitability, and blue, areas of low suitability. Species distribution model was generated using MaxEnt v 3.4.1 (Elith et al. 2006) and the set of WorldClim v 2.0 (Fick and Hijmans 2017) environmental variables. 
geostructural complexity of the Betic Mountain ranges, but are mainly dolomites, limestones, slates, phyllites, mycaschists, and, very locally, plutonic rocks (Sanz de Galdeano 1997; Vera 2004; Oliveira and Quesada 2019a, 2019b). It inhabits usually the thermoand meso-Mediterranean bioclimatic levels, and very locally at the supra-Mediterranean, with ombrotypes from semiarid to subhumid (Rivas-Martínez 1987; Rivas-Martínez et al. 2002; Valle 2003; Valle et al. 2004). According to the known localities and our observations, the species occurs in an extensive variety of habitats, with preference for more or less open forested areas with pines (Pinus halepensis, P. pinaster, P. nigra, both natural and reforested), oaks (Quercus ilex, Q. faginea and Q. suber in Sierra de Contraviesa), wild olive trees (Olea europaea var. sylvestris), and carob trees (Ceratonia siliqua L.), but also in shrub-lands of Quercus coccifera L., Genista umbellata (L'Hér.) Dum. Cours., Rosmarinus officinalis L., Pistacia lentiscus L., Pistacia therebinthus L., Buxus balearica Lam., Maytenus europaeus (Boiss.) Rivas Mart., R. sphaerocarpa, and Cistus and Lavandula L. species, among other typical shrubs (Rivas-Martínez and Costa 1987; Bolòs 1997; Valle 2003; Costa Tenorio et al. 2005). Sometimes, it has been found in almond tree crops (Prunus dulcis (Mill.) D.A. Webb) with scattered oaks (Q. ilex) (pers. obs.) (Fig. 7C, D).

Commonly found under bark or inside dead logs and stumps of pines ( $P$. halepensis, $P$. pinaster and P. nigra), and oaks (Q. ilex), or under stones in forests and shrublands. Occasionally found under the lose bark of standing live isolated Eucalyptus trees. In the island of Mallorca, it has been found in oak forests (Q. ilex), under bark or under stones and leaf litter (Español 1949, 1954a). Adults can be found in autumn, winter, and spring, with no records in the summer months of August and September.

\section{Misolampus scabricollis Graells, 1849}

Misolampus scabricollis Graells, 1849: 621. Terra typica: "Guadarrama”. Graells (1851a) mentioned the unavailable name "Misolampus graellsi Dufour".

Studied material. Portugal - Guarda: $2 \mathrm{~km}$ al O de Vale de Estrela, $977 \mathrm{~m}$, 40²9'35.7"N, 7¹9'12.1"W, 18-IV-2011: 1 ex.; [6 km al SO de] Guarda, 11-X-1992: 7 exx.; S. de Estrella [Serra da Estrela] (Sanz leg.): 1 ex. - Portalegre: Monte Palheiros, 632 m, 39²0'03.91"N, 7²5'38.63"W, 10-III-2012: 12 exx.; Ribeira de Nisa, [4 km al NE de Nisa], 23-X-1990: 1 ex. Spain - Andalucía: Huelva: Andalucía: Huelva: Cortegana, 706 m, 3753'55.6"N, 0650'16.3"W, 3-I-2013: 2 exx.; Cortegana: Puerto del Corzo (hacia Gil Márquez), 664 m, 3752'56.1"N, 0650'42.3"W, 3-I-2013: 9 exx. - Castilla - La Mancha: Ciudad Real: Fuencaliente (Sierra Morena) (J. Cabré leg.): 1 ex.; Navas de Estena: 2 exx.; Puebla de Don Rodrigo: El Vivero, 3902'29.2"N, 4³3'40.9"W, 5-III2012: 1 ex.; Saceruela: 1 ex., plus 1 without label; Guadalajara: 3 km al O de La Mierla, 1023 m, 4056'27.6"N, 3¹6'13.4"W, 26-X-2013: 12 exx.; Alpedrete de la Sierra, hacia el Atazar, 17-IV-1992: 3 exx.; Retiendas: Embalse del Vado, $931 \mathrm{~m}, 41^{\circ} 00^{\prime} 09.8^{\prime \prime} \mathrm{N}$, 317'41.6"W, 26-X-2013: 2 exx.; Umbralejo, 1256 m, 41 $07^{\prime} 33.2^{\prime \prime} \mathrm{N}, 3^{\circ} 10^{\prime} 39.4^{\prime \prime} \mathrm{W}$, 26-X-2013: 18 exx.; Toledo: Belvís de la Jara (N502 km 153), 584 m, 3943'59.3"N, 458'14.6"W, 1-XI-2008: 1 ex.; Las Honfrías, Robledo del Mazo, 39³5'48"N, 
0453'15"W, 9-II-2011: 1 ex.; Navamorcuende: Sierra de San Vicente: El Piélago, 1154 m, 4008'34.4"N, 444'09.2"W, 27-XII-2011: 3 exx.; Sierra de San Vicente: El Piélago, 1224 m, 400' $03.91 " N$, 4²3'48.79"W, 13-V-2012: 1 ex. - Castilla y León: Ávila: Chamartín de la Sierra: Castro de la Mesa de Miranda, 4043'24.7"N, 456'57.6"W, 10-II-2013: 1 ex.; [Navarredonda de] Gredos: 1 ex.; [Navarredonda de] Gredos (J. Ardois leg.): 10 exx.; Arenas [de San Pedro] (J. Ardois leg.): 1 ex.; Ávila (197) (Pérez leg.): 1 ex.; Casillas, $1158 \mathrm{~m}, 40^{\circ} 19^{\prime} 25.6^{\prime \prime} \mathrm{N}, 4^{\circ} 35^{\prime} 14.0^{\prime \prime W}, 16-X I-2012: 1$ ex.; Casillas: 4 exx.; Las Navas [del Marqués]: [Sierra de] Guadarrama (G. Schramm leg.): 75 exx.; 5 km S Navas del Marqués, 40³3'24.4"N, 4¹9'32.5"W, 1-IV-2013: 1 ex.; Mombeltrán - Navalperal: 2 exx.; Navalperal [de Tormes], VII-1904 (Escalera leg.): 1 ex.; Navamorcuende (Ardois leg.): 1 ex.; Navas del Marqués: Carretera de Valdemaqueda, $1021 \mathrm{~m}$, $0^{\circ} 32^{\prime} 14.3^{\prime \prime N}, 4^{\circ} 20^{\prime} 26.5^{\prime \prime W}, 20-I I I-2010: 1$ ex.; Peguerinos: Valle de Enmedio, 1-VII1992: 2 exx.; Puerto de Casillas, 1590 m, 40²0'37.1"N, 4³5'06.7"W, 15-V-2011: 1 ex.; Sierra de Gredos: 2 exx.; Valle de Iruelas, 10-V-1919 (J. Abajo leg.): 8 exx.; Valle de Iruelas, V-1920: 7 exx.; Villarejo [del Valle]): 1 ex. plus 1 without label; Burgos: Quemada, 848 m, 41 $43^{\prime} 20.4^{\prime \prime N}, 3^{\circ} 33^{\prime} 00.3^{\prime \prime W}, 9-V-2013: 4$ exx.; Salamanca: 1 km al N del Puerto de Perales, 884 m, 40¹5'18.3"N, 641'22.2"W, 16-IV-2011: 2 exx.; Navasfrías, 959 m, 40¹7'03.1"N, 649'49.1"W, 23-XII-2011: 9 exx.; Peña de Francia: 1 ex.; Puerto de Perales, 917 m, 40¹4'46.2"N, 641'20.5"W, 22-XII-2011: 3 exx.; Serradilla del Llano, 13-X-1992: 2 exx.; Segovia: Balsaín (C. Bolívar leg.): 1 ex.; Balsaín (J. Abajo leg.): 1 ex.; Balsaín (J. Ardois leg.): 15 exx.; Collado Ventoso, 1964 m, 4047'13.2"N, 402'32.8"W, 11-VIII-2013: 3 exx.; El Espinar: 1 exx.; Puerto de Los Cotos - Dos Hermanas, 4049'27.1"N, 357'51.4"W, 19-XI-2012: 1 ex.; Puerto de Los Cotos Dos Hermanas, 1900 m, 2-IX-1991: 2 exx.; Puerto de Navacerrada, 4047'11"N, $4^{\circ} 01^{\prime} 05^{\prime \prime W}, 13-V-2012: 1$ ex.; Puerto de Navacerrada, 4047'17.83"N, $4^{\circ} 00^{\prime} 36.27^{\prime \prime W}$, 30-V-2012: 1 ex.; Zamora: Santa Ana, 872 m, 41²'17.66"N, 6²4'22.65"W, 25-IV2012: 11 exx. - Extremadura: Cáceres: Alcuéscar, I-1894: 2 exx.; Carretera Villamiel - San Martín de Trevejo, 868 m, 40¹1'43.8"N, 647'30.3"W, 23-XII-2011: 6 exx.; Casares de Las Hurdes: Puerto de Robledo, 1074 m, 40²7'07.06"N, 6¹7'48.82"W, 17-IV-2012: 4 exx.; Hurdes: 1 exx.; Madrigal [de la Vera]: 1 exx.; Madrigal [de la Vera] (J. Ardois leg.): 21 exx.; Pico Villuercas, 1394 m, 39²8'19.72"N, 5²3'54.70"W, 12V-2012: 7 exx. - Madrid: Dehesa de Braojos, 1400 m, 4103'27.4"N, 3³8'51.1"W, 12-X-2013: 1 ex.; Cadalso [de los Vidrios] (J. Ardois leg.): 3 exx.; Cercedilla, 1460 m, VII-1945 (L. Esteban leg.): 1 ex.; Cercedilla, 1500 m, VIII-1935 (J. Hernández leg.): 4 exx.; Cercedilla, [Sierra de] Guadarrama (G. Schramm leg.): 11 exx.; Cercedilla, [Sierra de] Guadarrama (E. Zarco leg.): 2 exx.; Cercedilla (Lauffer leg.): 1 exx.; Cercedilla (Moróder leg.): 10 exx.; Cercedilla (Exp. del Museo): 20 exx.; Cercedilla (C. Bolívar leg.): 23 exx.; Cercedilla, 25-VII-1926: 1 ex.; Cercedilla (J. Ardois): 5 exx.; Cercedilla (Museo): 5 exx.; Cercedilla: 6 exx.; Cercedilla: El Ventorrillo, 1480 m: VIII-1960 (J. Abajo leg.): 2 exx.; Cercedilla: El Ventorrillo, 1478 m, 4045'17.3"N, 401'21.6"W, 11VI-2013: 11 exx.; Cercedilla: Estación Alpina, 1460 m (J. Abajo leg.): 1 ex.; Cercedilla: Estación Alpina, 1500 m: 2 exx.; Cercedilla: Estación Alpina, XII-1941 (E. Zarco leg.): 1 ex.; El Escorial (J. Dusmet leg.): 1 ex.; El Escorial (Misolampus scabricollis Graells): 1 ex. plus 1 without label; El Escorial, 10-V-1926: 3 exx.; El Escorial, 10-VI-1927: 
2 exx.; El Escorial, 20-V-1925: 2 exx.; El Escorial, 22-V-1953 (W. Steiner leg.) (T-29) (Misolampus scabricollis Graells, F. Español det.): 4 exx.; El Escorial (C. Bolívar leg.): 4 exx.; El Escorial: 4 exx.; El Escorial (Lauffer leg.): 5 exx.; El Escorial: Cuelgamuros, 1337 m, 40³8'53.8"N, 409'19.8"W, 10-VI-2013: 9 exx.; El Escorial: Puerto [de Malagón]: 1 ex.; El Paular (Exp. del Museo): 11 exx.; Garganta de Los Montes, 1346 m, 4054'46.9"N, 340'05.5"W, 26-V-2013: 2 exx.; Lozoyuela, 1288 m, 4055'31.4"N, $3^{\circ} 39^{\prime} 44.9 " \mathrm{~W}, 26-\mathrm{V}-2013$ : 5 exx.; Manzanares [El Real], 30-III-1928: 1 exx.; Manzanares El Real, 1156 m, 4045'28.1"N, 354'56.0"W, 28-II-2012: 3 exx.; Pelayos de la Presa, 799 m, 40²0'19.40"N, 4²1'34.84"W, 3-III-2001: 1 ex.; Puerto de Cotos, 12-VIII-1925: 1 ex.; Puerto de La Hiruela, $1354 \mathrm{~m}, 41^{\circ} 03^{\prime} 42.5^{\prime \prime} \mathrm{N}, 3^{\circ} 28^{\prime} 36.8^{\prime \prime W}$, 6-IV-2011: 1 ex.; Puerto de La Puebla, 1633 m, 4102'27.7"N, 328'48.9"W, 27-IV2011: 3 exx.; Puerto de Navacerrada, 18-VIII-1923): 1 ex.; Puerto de Navacerrada (E. Zarco leg.): 2 exx.; San Lorenzo del Escorial, 40³5'58"N, 409'42"W, 14-III-2015 (A. Sánchez Vialas): 2 exx.; Santa María de la Alameda (estación), 1-IV-1991: 1 ex.; Santa María de la Alameda, 1437 m, 40³6'11.11"N, 4º'15'18.93"W, 30-V-2012: 1 ex.; Sierra de Guadarrama (Lauffer leg.): 2 exx.; Tablada, 12-V-1957 (J. Álvarez leg.): 1 ex.; Valdemanco, $1090 \mathrm{~m}, 40^{\circ} 51^{\prime} 10.5^{\prime \prime} \mathrm{N}, 3^{\circ} 38^{\prime} 48.5^{\prime \prime W}, 8-\mathrm{V}-2013$ : 1 ex.

Diagnosis. Total length 11-13 mm (Graells 1849, 1851a, 1851b; Reitter 1917; Español 1949; López-Pérez 2014a). Pronotum with strong punctation intermixed with raised granules and small tubercles, particularly developed on the lateral sides, which gave them a strongly rugose appearance. Propleural sides with dense strong punctation. Elytra smooth, without traces of striae, series of punctures, or tubercles (Fig. 9A, B). Female genitalia figured by Palmer (1998) and aedeagus by Español (1949). Morphological variability seems to be restricted to individual variation in size and in the extent of the pronotal rugose areas.

Geographic distribution. Endemism of Portugal and Spain (Löbl et al. 2008) (Fig. 10). Bibliographic records are scarce, covering a large portion of the centre and western areas of the Iberian Peninsula, including Aveiro, Bragança, Alto Douro, and Guarda in Portugal, and the provinces of Ávila, Cáceres, Huelva, Madrid, Ourense, and Segovia in Spain (Graells 1849, 1851a, 1851b; Seidlitz 1867; Paulino de Oliveira 1894; Reitter 1917; De la Fuente 1934-1935; Español 1949; López-Pérez 2014a; Novoa et al. 2014). Published records of M. scabricollis from Sierra Espuña (von Heyden 1884), Murcia (De la Fuente 1934-1935) and Sierra de Alcaraz (Reitter 1917) are erroneous and probably correspond to M. subglaber. Misolampus scabricollis is widely distributed throughout the main mountain ranges of the central and western areas of the Iberian Peninsula (Sistema Central, Sierra de Gata, Sierra de Guadalupe, Montes de León, Montes de Toledo, eastern Sierra Morena, Serra da Estrêla), with an apparently isolated population in the western extreme of Sierra Morena (Sierra de Aracena, province of Huelva) separated ca. $240 \mathrm{~km}$ from the eastern population of this same mountain system (Fig. 10A).

All previously existing records except those of Huelva and Ourense, correspond to data published more than 70 years ago. The material studied or collected by us, includes records from all provinces of Spain previously reported in the literature, except from Ourense, with the addition of new records from Castelo Branco and Portalegre in Portugal, and from the provinces of Burgos, Ciudad Real, Guadalajara, Salamanca, 


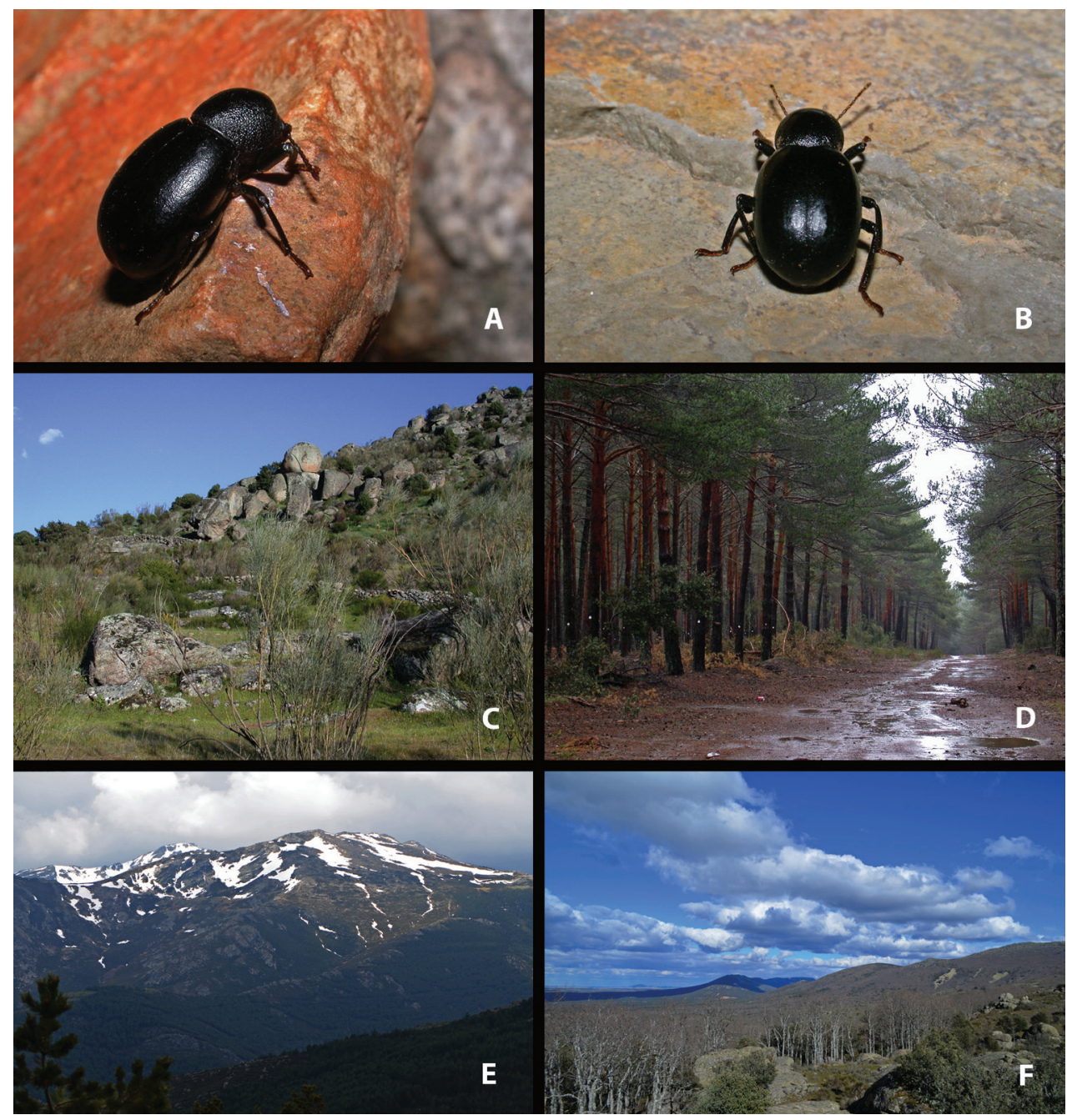

Figure 9. Live specimens and habitat of Misolampus scabricollis A, B live adult specimens of Misolampus scabricollis from Spain (A Sierra de Guadalupe, Cáceres B Las Honfrías, Montes de Toledo) C-F typical habitats of M. scabricollis (C granitic outcrops with Cytisus, Juniperus communis, and Quercus ilex along the Sistema Central Mountain Chain, Avila D densely reforested area with Pinus sylvestris at Santa Ana, Zamora) E Pinus sylvestris forests at the southern slopes of Pico del Lobo, Guadalajara F dense forests of Quercus pyrenaica at Montes de Toledo). Photographs by MGP.

Toledo, and Zamora in Spain. All these new records correspond to recent observations, together with old ones for Ciudad Real and Salamanca. The potential distribution map for this species (Fig. 10B) locates the main high suitable areas in central and western regions and along mountain ranges of the Iberian Peninsula. The SDM does not consider the isolated population of Sierra de Aracena as present in a high suitability area.

Notes on natural history. Misolampus scabricollis is a medium-low mountain species, with an elevation range of 224 to $1964 \mathrm{~m}$ a.s.l. (78\% of the records are above 

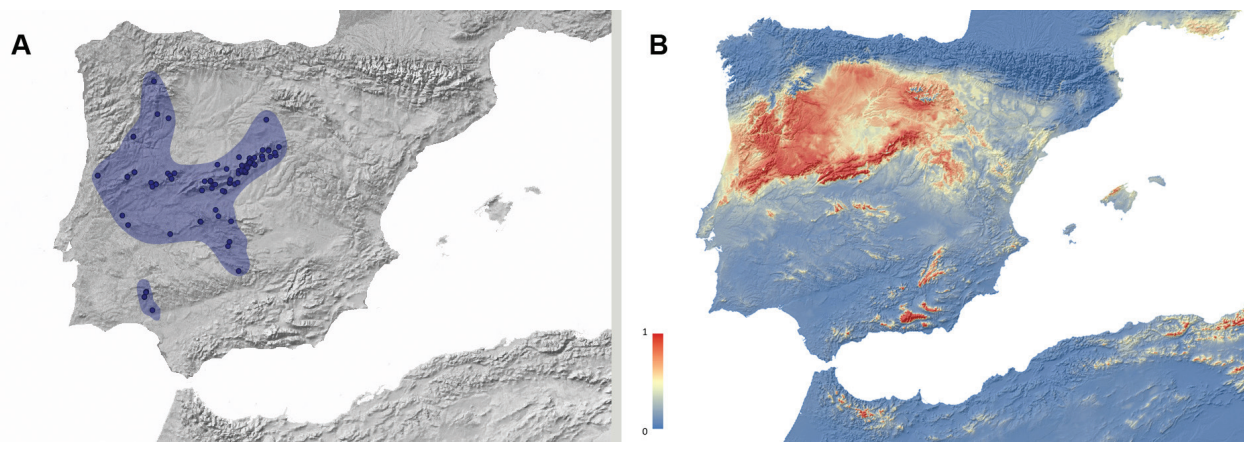

Figure 10. A Geographic distribution of Misolampus scabricollis. Distribution range of the Iberian endemic Misolampus scabricollis (dark blue spot). Blue dots correspond to the species records, including both recent and old, as well as previously published data. The populations from Huelva (southwestern Spain) remain isolated, since no intermediate populations are known in a distance of at least $150 \mathrm{~km}$, however intervening habitat seems favourable in many areas B potential geographic distribution of Misolampus scabricollis: Red indicates areas of high suitability, and blue, areas of low suitability. Species distribution model was generated using MaxEnt v 3.4.1 (Elith et al. 2006) and the set of WorldClim v 2.0 (Fick and Hijmans 2017) environmental variables.

$800 \mathrm{~m}, 56 \%$ above $1000 \mathrm{~m}$ of altitude). Lithological materials of its area of occupancy are siliceous and very diverse, mainly granites, schists, gneisses, quartzites, and plutonic rocks (Vera 2004; Oliveira and Quesada 2019a, 2019b). Most of its distribution area is located in the meso- and supra-Mediterranean thermoclimatic belts, and more locally at higher altitude in the oro-Submediterranean (exceptionally, one location is in the upper thermo-Mediterranean: Niebla, province of Huelva), with ombrotypes dry, subhumid and humid (Rivas-Martínez 1987; Rivas-Martínez et al. 1987, 2002; Valle et al. 2004; Rivas-Martínez 2007). It occurs in a large variety of forested habitats with different degrees of coverage, usually composed by pines (Pinus sylvestris, P. pinea, P. pinaster, natural or reforested), oaks (perennial: Quercus suber, Q. ilex; deciduous: Q. pyrenaica, Q. faginea) and chestnut trees (Castanea sativa), as well as substitution shrubs, mainly of Cistus, Cytisus, Ulex L. and Genista L. (Ladero 1987; Rivas-Martínez 1987; RivasMartínez et al. 1987; Valle 2003; Costa Tenorio 2005) (Fig. 9C-F).

According to our observations, M. scabricollis is usually found inside dead and decaying tree trunks, or under bark, usually in standing or lying pine logs, oaks, and chestnut trees. These observations are coincident with the few disperse available data on the habitat of this species (Graells 1851a, 1851b; López-Pérez 2014a). Areas covered by dense bushes of $Q$. pyrenaica and $Q$. ilex (recovering after fires or logging) are also frequently used by this species. Misolampus scabricollis can also be found in areas reforested with pines, and under stones, small pieces of wood, or inside tight clusters of branches, in shrub areas dominated by Cytisus scoparius, C. oromediterraneus, and less frequently by Cistus ladanifer (Fig. 9C-F). They are usually more easily found on logs and under stones at the edge of dense forests, but they can also be found deep inside the forest or in nearby grasslands. 
This species is usually found forming small groups of 2-21 specimens in a single log. Graells (1851a, 1851b) reported groups of five or six specimens per log in the Guadarrama Mountains. According to Graells (1851a, 1851b), when disturbed they pretend to be dead (thanatosis) and expel an unpleasant light odour.

Misolampus scabricollis has been found in microsympatry with M. gibbulus along western Sierra Morena (Huelva), northern Extremadura (Cáceres), Montes de Toledo (Toledo) and southern slopes of the Sistema Central (Madrid, Ávila, Toledo) (Fig. 1E), however, M. scabricollis is usually found at higher altitudes than M. gibbulus. Adults can be found across most of the year, but are more easily encountered during the wetter, colder, months (October to May). It is often found in company of Coelometopus clypeatus in old chestnut trunks.

\section{Misolampus subglaber Rosenhauer, 1856}

Misolampus subglaber Rosenhauer, 1856: 204. Terra typica: "in der Sierra de Ronda".

Studied material. SpaIN - Andalucía: Córdoba: Córdoba: 1 ex.; Granada: Güejar Sierra: 1 ex.; La Sagra (Escalera 1900): 4 exx.; Puebla de Don Fadrique (Escalera 1900): 5 exx.; Puebla de Don Fadrique: Nablanca, 1517 m, 3800'23.6"N, 2²8'28.2"W, 10-IV-2011: 2 exx.; Valdeiglesias, 975 m, 36 $56^{\prime} 49.3 " \mathrm{~N}, 4^{\circ} 04^{\prime} 29.6^{\prime \prime W}, 24-X-2019: 3$ exx.; Jaén: $3 \mathrm{~km}$ SO Aldeaquemada, 38²3'53.7"N, 324'00.5"W, 7-III-2012: 5 exx.; [3 km al SO de] Aldeaquemada, 26-IV-1992: 2 exx.; Cazorla: 7 exx.; Vadillo de Castril, Sierra de Cazorla, 995 m, 3755'14"N, $2^{\circ} 55^{\prime} 50^{\prime \prime W}, 8-V-2008$ (D. Ruiz leg.): 1 ex.; Santa Elena, carretera hacia La Aliseda, 768 m, 38²0'18.0"N, 3³2'56.8"W, 11-IV-2011: 3 exx.; Santa Elena, carretera hacia La Aliseda, 795 m, 38²0'53.1"N, 03³3'20.6"W, 28-XII-2010: 1 ex.; Santiago de la Espada (J. Martínez): 1 ex.; Segura [de la Sierra]: 1 ex.; Sierra Morena (Laguna leg.): 1 ex.; Málaga: 3 km al E de Jubrique, 786 m, 36³3'37.5"N, 5¹0'40.9"W, 14-IV-2013: 6 exx.; Nerja: 1 ex.; El Colmenar, Gaucín, P.N. Los Alcornocales, 255 m, 36²'29"N, 5²3'22"W, 17-II-2018 (S. Yubero leg.): 3 exx.; Carril Llanada de Sedella-Bco. de Valdeinfierno, Sierras de Tejeda y Almijara, 1495 m, 36 53'15"N, 356'40"W, 4-I-2017: 2 exx. - Castilla - La Mancha: Albacete: Agramón: 2 exx., plus 1 without label; Alcaraz: 3 exx.; Calar del Mundo, V-1904 (G. Schramm leg.): 1 ex.; Cañadillas, 15-VI-1938: 1 ex.; Cañadillas, 16-VI1938: 1 ex.; Cañadillas, 17-VII-1938: 1 ex.; Los Collados, 20-II-1938: 1 ex.; Molinicos: 1 ex., plus 4 exx. without labels; Riópar, 25-VII-1926: 1 ex.; San Juan de Alcaraz [Fábricas de Riópar] (Paz leg.): 1 ex.; Ciudad Real: Solana del Pino: Puerto Madrona, 38 $25^{\prime} 07.3^{\prime \prime} \mathrm{N}, 4^{\circ} 03^{\prime} 33.1^{\prime \prime W}, 06-I I I-2012: 3$ exx.; Cuenca: Puerto de Cabrejas, $1167 \mathrm{~m}, 40^{\circ} 04^{\prime} 17.9^{\prime \prime} \mathrm{N}, 2^{\circ} 18^{\prime} 39.5^{\prime \prime W}, 10-X I-2012: 1$ ex. - Murcia: Jumilla: 3 exx.

Diagnosis. Total length 10-12 mm (Reitter 1917; Español 1949). Species clearly characterised by the combination of the following traits: smooth silky appearance; antennae graceful, reaching the base of pronotum; pronotal punctation very fine and sparse on the disc, somewhat stronger and denser to the sides; elytral punctation very fine and 
irregular, not forming longitudinal series of points or striae (Reitter 1917; Español 1949; Palmer 1998) (Fig. 11A, B). Female genitalia figured by Palmer (1998). The species has been studied karyologically and presents $2 \mathrm{n}=20$ chromosomes (Palmer and Petitpierre 1997). Morphological variability within this species seems limited to the depth and density of pronotal punctation, and it does not appear geographically structured.

Geographic distribution. Endemism of southeastern Spain (Löbl et al. 2008) (Fig. 12). Published records are scarce, but well distributed throughout Andalucía: Granada, Jaén, Málaga; Castilla - La Mancha: Albacete; Comunidad Valenciana: Valencia; and Murcia (Rosenhauer 1856; Piochard 1866; Reitter 1917; De la Fuente 1934-1935; Cobos 1949; Español 1949, 1960; Molino Olmedo 1996; Palmer and Petitpierre 1997; Ibáñez Orrico 2002; Pérez and López-Colón 2010; López-Pérez 2014a sub M. erichsoni, 2014b; Grimm and Aistleitner 2009; Bujalance de Miguel 2015). Records are distributed through time in all areas, except for the recent one from Valencia region (Fig. 12A).

The material studied or collected by us includes specimens from all provinces reported in the literature, except from Valencia. In addition, we studied material from the provinces of Córdoba, Ciudad Real and Cuenca; specimens of Ciudad Real and Cuenca are represented by recent collections (2012). According to these data, M. subglaber is located in the Betic Mountain range (Sierras del Campo de Gibraltar, Serranía de Ronda, Sierra Nevada, Sierras de Tejeda and Almijara, Sierra de Cazorla, Sierra de

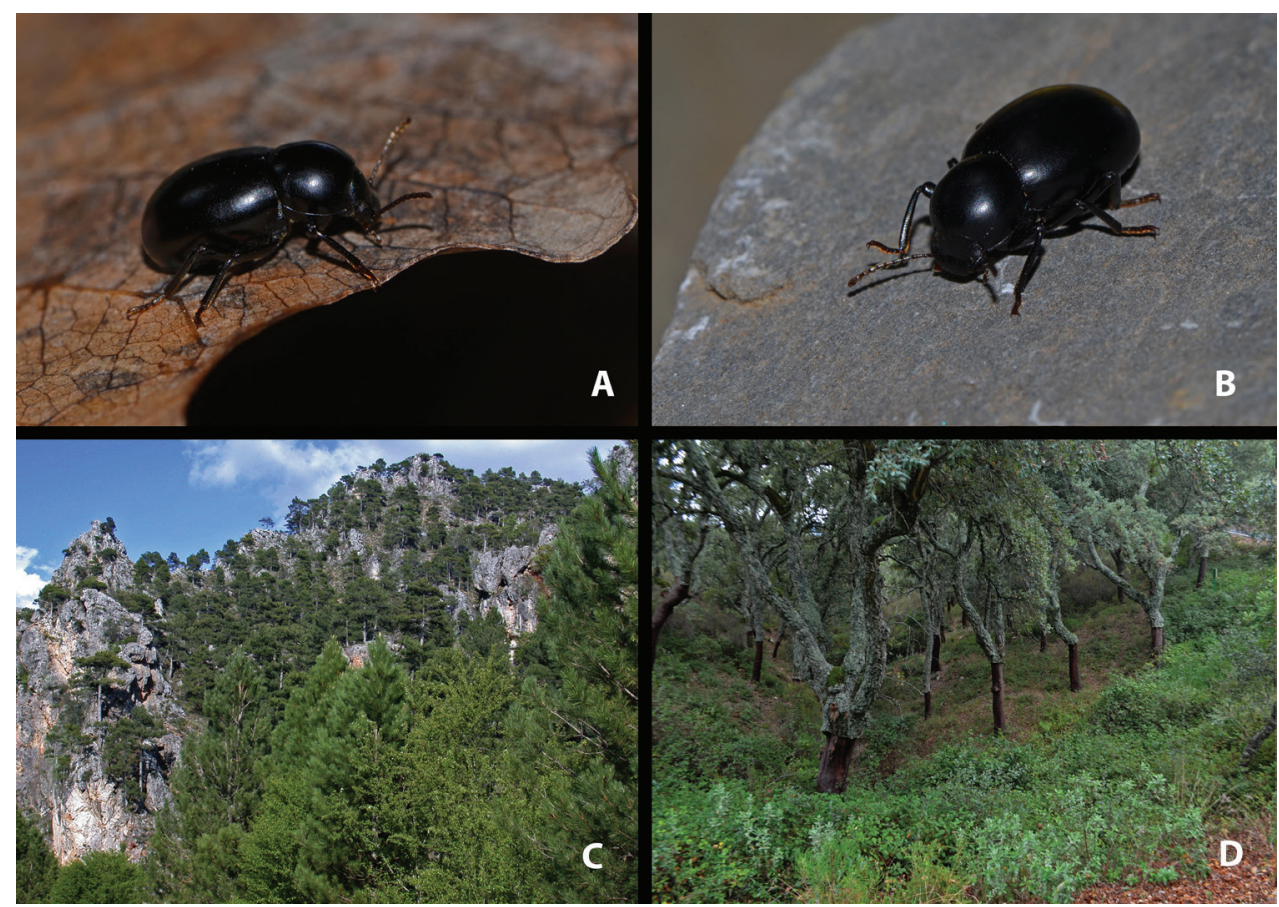

Figure I I. Live specimens and habitat of Misolampus subglaber A, B live specimens of Misolampus subglaber from Spain (A Valdeiglesias, Sierra Tejeda, Granada B Miranda del Rey, Sierra Morena, Jaén) C, D general habitat occupied by M. subglaber (C limestone outcrops with Pinus nigra along the Sierra de Alcaraz, Albacete D Quercus suber forests at Cortes de la Frontera, Sierra de Grazalema, Málaga). Photographs by MGP. 
Alcaraz, Sierra de Cartagena), eastern and central Sierra Morena mountain range, and two apparently isolated populations in the Southern Iberian mountain range (Serranía de Cuenca and Sierra de Malacara, separated between them by ca. $150 \mathrm{~km}$ ). There is a gap of records in the arid regions of the southeastern end of Spain, throughout the provinces of Almería and southern Murcia, including the eastern half of Sierra Nevada and Sierra de Filabres. The record from Cartagena, Murcia (Reitter 1917), requires further confirmation (Fig. 12A). The potential distribution map identifies the Betic Mountain ranges as the most suitable area for the species. The coastal areas of Almería, Granada, and Málaga provinces are however not included as very suitable. The southern Iberian Plateau and the northwestern African mountain ranges are also suggested as areas of high suitability for the species occurrence (Fig. 12B).

Notes on natural history. Misolampus subglaber behaves as a low-medium altitude montane element, distributed within an altitudinal range of 56 to $1662 \mathrm{~m}$ a.s.l. (with $61 \%$ of its records above $800 \mathrm{~m}$ ). Geological substrates along its distribution area are diverse, both acid and basic, including mainly sandstones, limestones, dolomites, slates, gneisses, schists and mycaschists (Sanz de Galdeano 1997; Vera 2004; Oliveira and Quesada 2019a, 2019b). Misolampus subglaber occupies mostly the thermo- and meso-Mediterranean thermoclimatic belts and locally supra-Mediterranean, in areas with ombrotype semiarid, dry, subhumid and, exceptionally, humid (Rivas-Martínez 1987; Rivas-Martínez et al. 2002; Valle 2003; Rivas-Martínez 2007). It occurs on an extensive variety of pre-forest and forest systems, more or less dense and open, including oaks (deciduous: Quercus pyrenaica, Q. canariensis and Q. faginea; perennial: Q. suber and Q. ilex) and pines (natural or reforested: Pinus nigra, P. pinaster, P. halepensis, and P. sylvestris), all of them usually with diverse undergrowth (Alcaraz Ariza and Peinado Lorca 1987; Peinado Lorca and Martínez Parras 1987; Laguna 1997; Valle 2003; Costa Tenorio et al. 2005) (Fig. 11C, D).

A

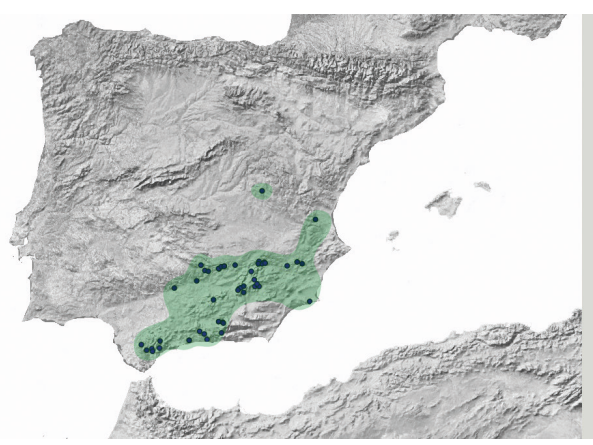

B

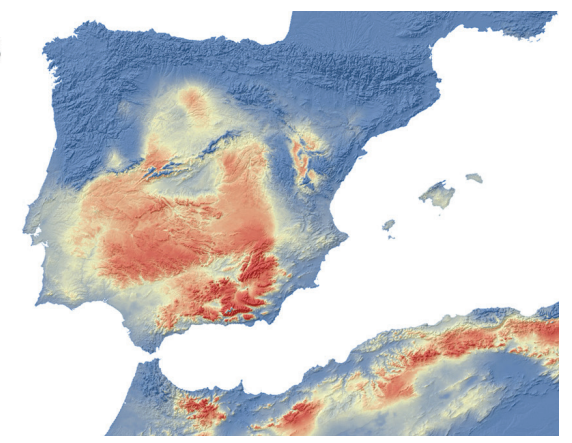

Figure 12. A Geographic distribution of Misolampus subglaber. Distribution range of Misolampus subglaber (green spot). Blue dots correspond to the species records, including both recent and old, as well as previously published data. Cuenca population is isolated from all other known populations by a distance of $150 \mathrm{~km}$. The old bibliographic record from Cartagena (province of Murcia, south western Spain) requires confirmation B potential geographic distribution of Misolampus subglaber: Red indicates high suitable areas, and blue, areas of low suitability. Species distribution model was generated using MaxEnt v 3.4.1 (Elith et al. 2006) and the set of WorldClim v 2.0 (Fick and Hijmans 2017) environmental variables. 
Adult specimens of $M$. subglaber have been found at the base and under mosses of old oak trunks and inside hollow branches on the ground (Q. suber, Q. pyrenaica, $Q$. canariensis, Q. faginea) (Fig. 11D), inside rotten logs, and under stones and leaf litter in pine forests (P. nigra, P. pinaster, P. halepensis) (Piochard 1866; Español 1960; Molino Olmedo 1996; Ibáńez Orrico 2002; pers. obs.). Pérez and López-Colón (2010) found a specimen inside a natural cavity in the province of Jaén, where it possibly came by stochastic passive dispersal. Often found in groups (Español 1960; pers. obs.).

Molino Olmedo (1996) found larvae inside decaying wood of branches and logs of Q. pyrenaica, Q. canariensis, Q. faginea, Q. suber, Q. ilex and P. pinaster and Ibañez Orrico (2002) on rotten logs of $P$. halepensis (however, the larva of $M$. subglaber has not been described yet). According to Molino Olmedo (1996), M. subglaber is a typical saproxylic species.

The general distribution area occupied by M. subglaber (Fig. 12) is largely coincident with that of $M$. ramburii (Fig. 8), however they have not been found in microsympatry, a possible indication of ecological segregation between them. Adults are mainly active in fall, winter and spring, but can be found all year round (pers. obs.). Large larvae and pupae have been observed at the end of August in Valencia (Ibañez Orrico 2002).

\section{Identification key for adult specimens of the genus Misolampus (modified from Español 1949)}

$1 \quad$ Elytra with series of deep to shallow punctures forming strongly to almost erased, excavated striae; additional series of punctures often present on the elytral intervals (Fig. 14A, B). Small size (6.9-12 mm) .2

- $\quad$ Elytra without any trace of longitudinal series of punctures forming striae (Fig. 14C, D); if very weak striae are present, then interstriae show slightly raised longitudinal series of more or less developed and separated tubercles (Fig. 14D). Medium to small size (7.5-14 mm).

2 Anterior angles of pronotum slightly prominent (Figs 15A, 1C). Elytra with poorly marked striae, formed by longitudinal series of shallow to almost erased punctures; interstriae smoothly curved (Figs 7, 14A) .....

M. ramburii

- $\quad$ Anterior angles of pronotum markedly prominent (Figs 15B, 16D). Elytra with strong to shallow striae, formed by longitudinal series of deep to shallow punctures; interstriae clearly convex (Figs 1, 14B)

M. gibbulus

3 Anterior angles of pronotum rounded, forming an open angle (Figs 16E, F). Elytra with shallow to almost erased striae, often showing longitudinal series of more or less developed elongated tubercles, or sometimes shallow fossae on the interstriae, better marked on the second half of the elytra and on the sides (Fig. 14D). Medium size (10-14 mm), long antennae (Fig. 3) M. goudotii

- $\quad$ Anterior angles of pronotum forming a widely acute to right angle (Figs 16A, B, 17). Elytra without any trace of striae or tubercles. Medium to small size (7.5-13 mm), relatively short antennae. 
Pronotum sculpture formed by deep large confluent punctures (Fig. 16A); the surface between punctures progressively transforms in irregular raised areas that become small irregular granules and wrinkles, giving a strongly rugose appearance to the pronotum sides (Figs 9, 16A). Medium size (11-13 mm)

M. scabricollis

- $\quad$ Pronotum sculpture formed by deep to shallow, dense or sparse, never confluent, well-defined punctures which cover all the pronotal surface, including the lateral sides, which can present somewhat more confused punctation, but not forming rugose areas (Fig. 16B). Large to small size.....

5 Elytra covered by dense punctures somewhat confused or partially erased at the disc. Pronotum sculpture formed by deep, dense, well-defined punctation. Antennae relatively short, not reaching the base of pronotum (Fig. 5). Small size $(7.5-8 \mathrm{~mm})$

M. lusitanicus

- $\quad$ Elytra covered with very fine, shallow and sparse punctation that gave a silky shine to the elytral surface (Fig. 14C). Pronotum sculpture formed by shallow, spaced, and very fine well-defined punctation (Fig. 16B). Antennae usually reaching the base of pronotum (Fig. 11). Medium size (10-12 mm)

M. subglaber

\section{Discussion}

\section{Comments on the taxonomy of Misolampus}

North African Misolampus were described originally as three independent entities: M. goudotii from Tanger in northwestern Morocco (Guérin-Méneville 1834), M. erichsoni from Algeria (Erichson in Wagner 1841; Vauloger de Beaupré 1900; Reitter 1917) (Fig. 3A), and M. peyerimhoffi from the High Atlas in Morocco (Antoine 1926) (Fig. 3B). Additional variability was recorded, but not published, in the labels assigned by M. Martínez de la Escalera to specimens from the Rif region (" $M . g$. var. riffensis" Escalera in litt.; "M. g. var. laevior" Alluaud in litt.) and from Ifni ("M. g. var. ifnicus" Escalera in litt.) (Fig. 3C) at the MNCN collection (París García et al. 2011). Antoine (1949) described morphologically intermediate populations (Middle Atlas) and showed that male genital structures were similar between the three taxa. Accordingly, Antoine (1949), followed by Español (1949, 1954a), considered that the morphological traits used to separate the three described North African taxa were insufficient, and treated them as subspecies (M. g. goudotii, M. g. erichsoni, and M. g. peyerimhoffi). Español $(1953,1967)$ went further, and suggested that M. g. erichsoni should be included in the synonymy of $M$. goudotii, while Kocher (1958) indicated that all three taxa were just local varieties of a unique taxon. However, the criterion of Español $(1953,1967)$ and Kocher (1958) was not followed by subsequent authors (Löbl et al. 2008). Meanwhile, the morphological variability implied by Martínez de la Escalera and Vauloger identifications (in litt.), raises further problems for the characterisation of North African populations as subspecies. 
Characters initially used for separation of the North African taxa were: pronotal punctation, shape of the anterior margin of the pronotum, shape and sculpture of the propleurae, and width of the second interstria on the elytra (Vauloger de Beaupré 1900; Antoine 1949; Español 1954a). A close examination of the specimens studied by Vauloger and Escalera (see materials and methods) reveals that some of the Rif specimens present intermediate traits between the specimens of the Tingitane Peninsula (Tanger, western Rif) and those from the Middle and High Atlas (Fig. 3B). At the same time, specimens from Ifni (Fig. 3C), roughly located at the coastal western end of the Anti-Atlas mountains, are more similar morphologically to the specimens from the Rif than to those geographically closer from the High Atlas.

Morphological similarity between specimens located in geographically isolated areas, separated by hundreds of kilometres, reflects that the morphological diversity documented across populations, lies within the phenotypic variability of a single evolutionary entity, rather than being a consequence of ancient isolation processes (Montori et al. 2008; Gonçalves et al. 2009). Alternatively, the observed morphological diversity could be consequence of a rapid response to recent geographic isolation of local populations subjected to local strong selective pressures (Velo-Antón et al. 2007). These hypotheses could be tested by genetic analyses, since the phylogeographic outcome of these two processes would be markedly different in each case: Geographically unstructured nuclear marker networks, accounting for the lack of geographic structure at the morphological level, with or without deep mtDNA lineage differentiation in the first case (Recuero and García-París 2011); or alternatively, geographically congruent nuclear and mtDNA marker phylogeographic patterns, with recent, shallow, multiple $\mathrm{mtDNA}$ lineage differentiation, accounting for the recency of the isolation processes, not enough to allow sorting out morphological differences, in the second case (Vörös et al. 2006; Rodríguez-Flores et al. 2017). However, none of these processes is consistent with the recognition of independent evolutionary units within North African Misolampus, and therefore we consider necessary to synonymise all three subspecies (M. goudotii Guérin-Méneville, $1834=$ M. erichsoni Vauloger de Beaupré, 1900, syn . nov. $=$ M. peyerimhoffi Antoine, 1926, syn. nov.), retaining thus a single North African species: $M$. goudotii Guérin-Méneville, 1834. The morphological similarity between the Balearic specimens and the Eastern Moroccan and Algerian ones drove Palmer and Cambefort (2000) to consider a very recent origin for the Balearic populations, possibly as a consequence of human-mediated dispersal.

There has been some confusion in the identification of specimens of Misolampus from southern Portugal (Serra de Monchique). Specimens from that region often present not strongly marked elytral striae, and relatively smooth thoracic impressions (Fig. 1A, B), resembling M. ramburii (Fig. 7A, B). However, a close examination of the Serra de Monchique specimens (Foia, Monchique, São Marcos da Serra) indicates that based on all other characters (mainly, prothorax morphology, and pronotal punctation), they correspond to $M$. gibbulus. The morphological differentiation shown by the population of M. gibbulus from Serra de Monchique with respect to other populations of the species, is quite marked, and led Reitter (1917), Paulino de Oliveira (1894) and De la Fuente (1934-1935) to mention erroneously the presence of M. ramburii in Serra de Monchique. 
A similar situation occurs within $M$. ramburii. Specimens from populations of Granada (Sierras de Contraviesa and Huétor) have smoother pronotal sculpture, and less marked, almost absent elytral striae (Fig. 7B), while specimens from Almería show stronger sculpturing in elytra and pronotum, with elytral striae, marked by a series of aligned punctation, faint, but visible (Fig. 7A). This contrasting variation is probably the reason Español (1963) reported an unidentified species of Misolampus from the Sierra de Contraviesa. Lack of elytral striae made these specimens key to M. subglaber, M. lusitanicus, or M. scabricollis using Reitter's (1917) identification table, but other characters, including pronotal structure, allow for an easy separation.

These evident patterns of morphological differentiation within M. ramburii, M. gibbulus, and $M$. goudotii may reflect a relatively recent history of isolation across populations, probably consequence of the existence of multiple isolated Pleistocene refugia (Abellán and Svenning 2014), as proposed for other flightless Iberian Coleoptera (Sánchez-Vialas et al. 2020). In any case, these hypotheses require phylogeographic analyses to be properly tested.

\section{Historical population continuity and current conservation status}

Species of Misolampus have often been considered to present allopatric or, at most, parapatric distributions (Palmer 1998; Palmer and Cambefort 2000). However, old records of Misolampus are, in most species, scarce and unevenly distributed. Indeed, by filling large gaps where no records were present, the newly gathered specimens allow for a better understanding of the distribution patterns of all species.

Our data show some level of sympatry among several species pairs (i.e., $M$. gibbulus - M. scabricollis, M. ramburii - M. subglaber), even with cases of microsympatric distribution. These levels of sympatry among ecologically similar, phylogenetically closely related taxa are not common because of demographic processes such as competitive exclusion (Hardin 1960; Waters et al. 2013). Assuming the existence of ecological niche overlap among species pairs of Misolampus, areas of sympatric distribution can be explained by simultaneous colonisation from their respective glacial refugia, rapidly spreading into areas with favourable habitats while population densities are still very low, allowing for the establishment of two species (Recuero and García-París 2011; Escoriza et al. 2016; Yackulic 2017). In this way, areas traditionally considered glacial refugia in the Iberian Peninsula (e.g., southern Portugal, Atlantic Coasts of Galicia and Northern Portugal, southeastern Spain) (Martínez-Solano et al. 2006; Sánchez-Montes et al. 2018), where population sizes would have remained high, and thus favouring processes as competitive exclusion, are typically inhabited by a single species of Misolampus. The species distribution models show that the species of Misolampus present almost complementary potential distributions, supporting the hypothesis that current sympatry areas are the result of recent contact among taxa. The map including highest suitability areas (suitability > 0.7 ) for all the Iberian species combined (Fig. 13), shows that most of the high suitable areas do not overlap. Species suitable areas remain mainly restricted to the following regions: $M$. gibbulus in the southwest, $M$. lusitanicus in the northwest, $M$. ramburii in the southern coasts, M. scabricollis over the northern Iberian Plateau, and M. subglaber in the southeastern areas of the Iberian Plateau and along the Betic Mountains. 


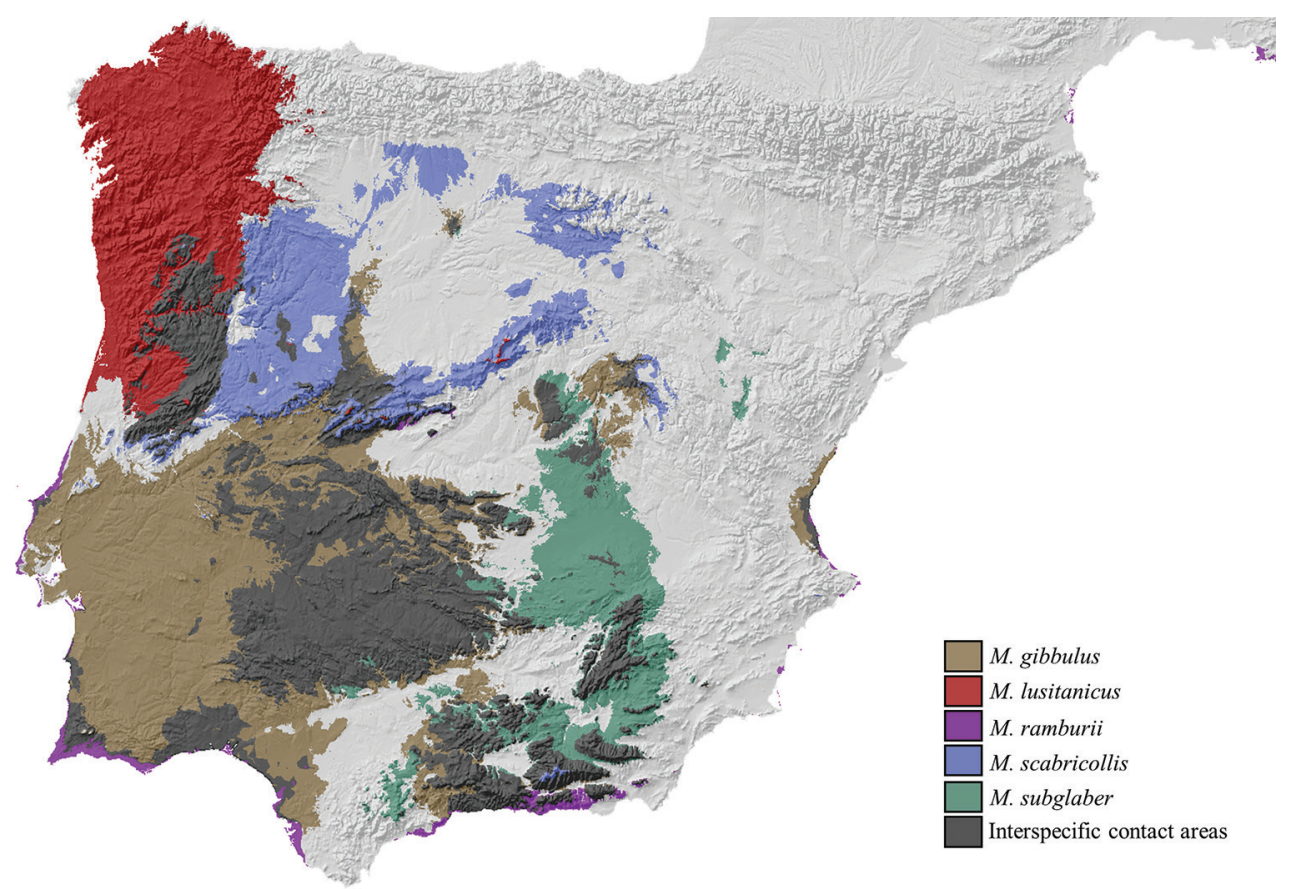

Figure 13. Map of the potential geographic distribution of the Iberian species of Misolampus, with the areas of high suitability (suitability $>0.7$ ) depicted for all the species combined: $M$. gibbulus (orange), $M$. lusitanicus (red), M. ramburii (purple), M. scabricollis (dark blue), M. subglaber (green). Dark grey areas correspond to interspecific contact areas. The areas of low suitability for the occurrence of Iberian species of Misolampus are represented in pale grey.

Additionally, our results indicate the presence of the genus in geographical areas where it had never been recorded. The absence of Misolampus from most part of the Sistema Ibérico mountain chain is particularly striking, considering the huge extension of favourable forest habitats. The recent finding of $M$. subglaber in the province of Cuenca, as well as the published record from the province of Valencia (Ibañez Orrico 2002), suggests that further populations could be discovered with more intensive sampling, at least in the southern parts of the Sistema Ibérico. Similarly, our records of M. scabricollis from the provinces of Burgos and Guadalajara are relatively close to the Sistema Ibérico mountains, where the species could be present, but still undetected. Similar cases of long undetected presence of arthropod species in the Sistema Ibérico have been recently published (Valladares et al. 2000; Pérez-Onteniente et al. 2015; Ruiz 2015; Recuero and Rodríguez-Flores 2019).

Field data collection, although essential, has the disadvantage of being limited across space, time and taxa, which can constitute a constraint for biodiversity monitoring and conservation (Kuussaari et al. 2009; Meineke et al. 2019). Lack of information on changes in biodiversity through time and on the direction of these changes can make it difficult to identify and counteract negative impacts derived from disturbances (Magurran et al. 2010). However, scientific collections hold in a single location an 


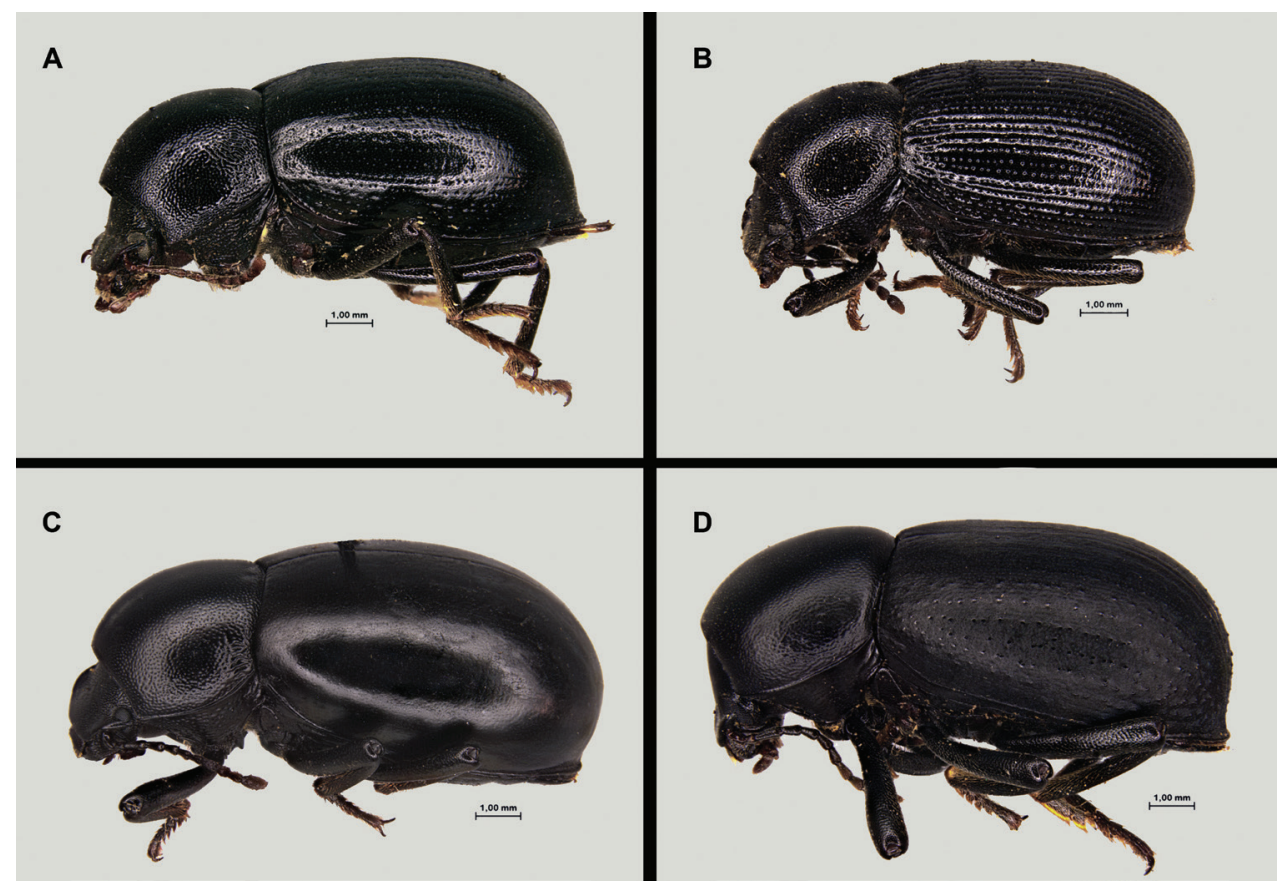

Figure 14. Lateral view of specimens of Misolampus A Misolampus ramburii from Málaga B Misolampus gibbulus from Santa Elena (Jaén) (MNCN_Ent 270070) C Misolampus subglaber from Cazorla (Jaén) (MNCN_Ent 270037) D Misolampus goudotii from Menorca Island (MNCN_Ent 270032). Note the marked differences in sculpture of elytra among all four species.
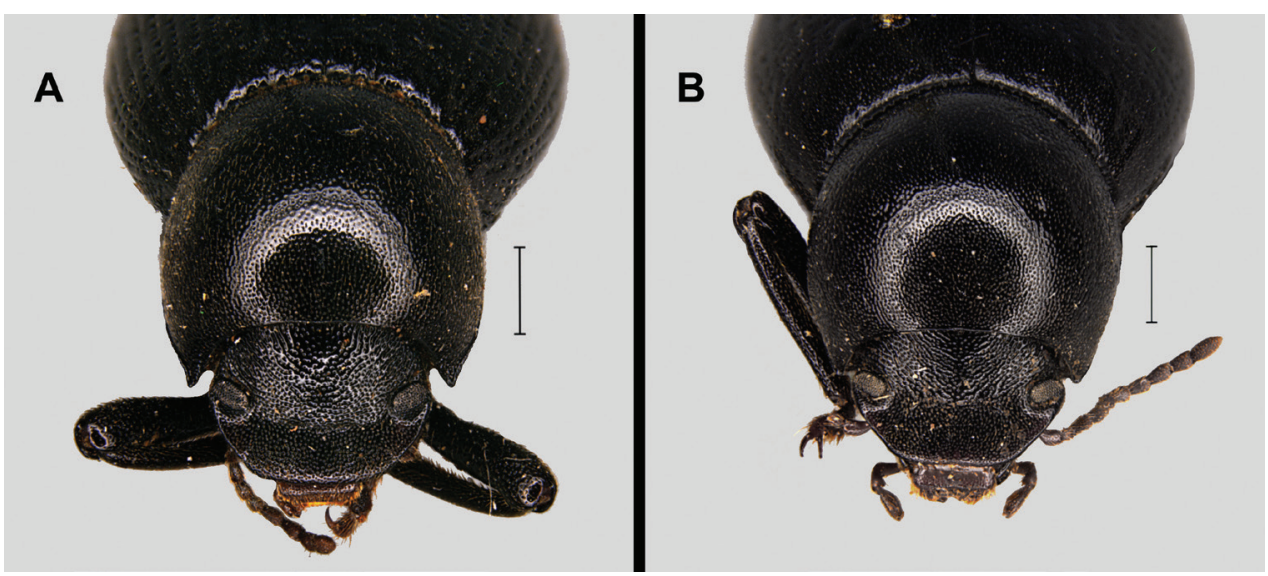

Figure 15. Fronto-dorsal view of specimens of Misolampus A Misolampus gibbulus from Santa Elena (Jaén) (MNCN_Ent 270070) B Misolampus ramburii from Málaga (MNCN_Ent 270037). Note the differences between the two species in the shape of the anterior angles of the prothorax. Scale bars: $1 \mathrm{~mm}$.

enormous amount of information regarding a wide variety of taxa and, even though their potential has been historically under-appreciated, they are currently considered invaluable resources for biological studies (Meineke et al. 2019; Salvador and Cunha 


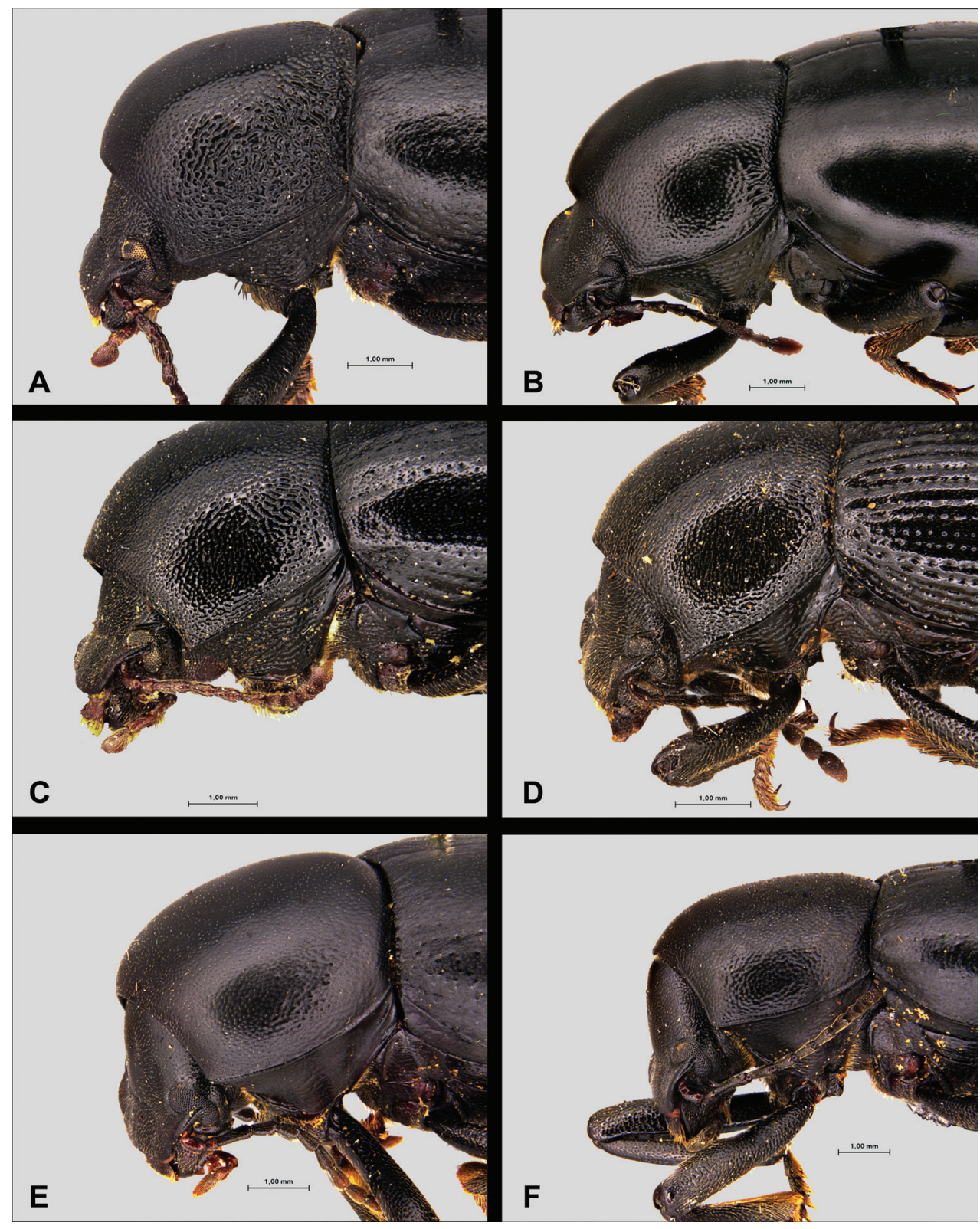

Figure 16. Lateral view of the head and prothorax of specimens of Misolampus $\mathbf{A}$ Misolampus scabricollis from Puerto de Navacerrada (Madrid) (MNCN_Ent 270049) B Misolampus subglaber from Cazorla (Jaén) (MNCN_Ent 270209) C Misolampus ramburii from Málaga (MNCN_Ent 270037) D Misolampus gibbulus from Santa Elena (Jaén) (MNCN_Ent 270070) E Misolampus goudotii from Menorca Island (MNCN_Ent 270032) F Misolampus goudotii from Iguermalen, Beni Mesdui (Rif Mountains, Morocco) (MNCN_Ent 270188). Note the marked differences in sculpture and anterior angles of pronotum among all five species represented. Photographs $\mathbf{E}, \mathbf{F}$ represent some of the geographic variability observed within M. goudotii. 


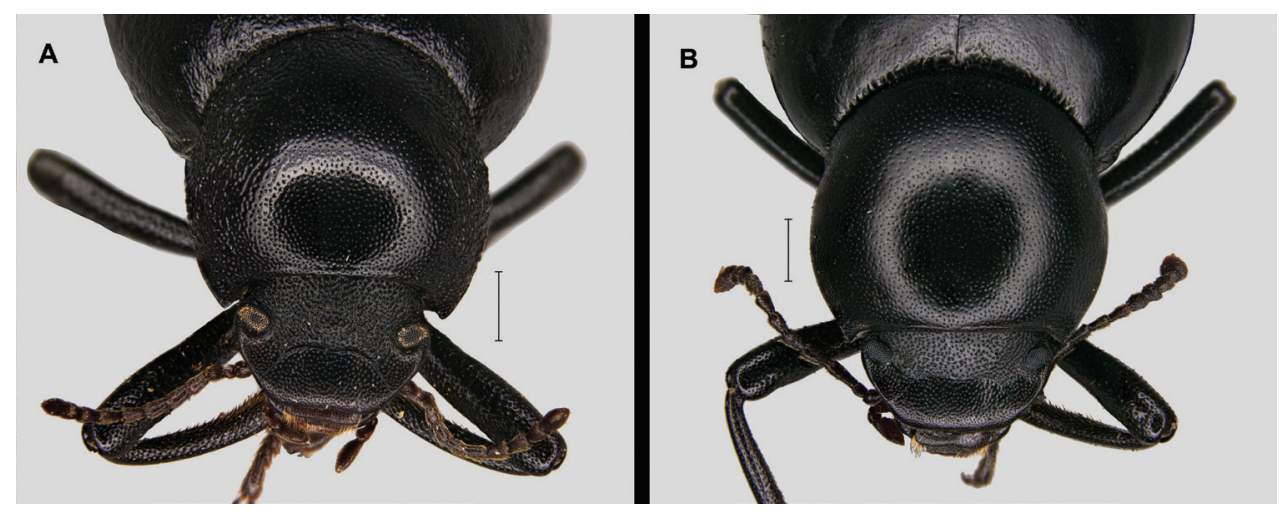

Figure 17. Fronto-dorsal view of specimens of Misolampus A Misolampus scabricollis from Puerto de Navacerrada (Madrid) (MNCN_Ent 270049) B Misolampus subglaber from Cazorla (Jaén) (MNCN_Ent 270209). Note the differences in the lateral sculpture of pronotum. Scale bars: $1 \mathrm{~mm}$.

2020). These collections provide data on taxon distributions over a vast time, offering a unique perspective on species response to habitat loss and fragmentation, land use intensification or climate change, thus providing critical information to reconstruct species decline and develop conservation strategies (Ponder et al. 2001; Suarez and Tsutsui 2004; Grixti et al. 2009; Doadrio et al. 2019).

The way scientific collections were gathered and the form in which they have been preserved, offer a vast array of possibilities for past-present comparisons in this era of biodiversity loss (Short et al. 2018). Large entomological collections are often formed by the addition of multiple smaller collections (Cambefort 2006; Doadrio et al. 2019). Each taxonomist's collection is a summary of the general biodiversity knowledge at the time, for each of their groups of study. In this sense, scientific collections represent temporal windows opened to a now unreachable past biodiversity, and access to them should be essential and promoted (Mantle et al. 2012; Short et al. 2018).

The saproxylic nature of Misolampus calls into question their conservation status, since saproxylic beetles have been identified as a highly threatened animal assemblage due to habitat loss derived from logging and the decline of veteran trees throughout the landscape (Davies et al. 2008; Ricarte et al. 2009; Nieto and Alexandre 2010; Marcos García and Galante 2013; García-López et al. 2016; García et al. 2018). Despite the potential threats to which the species of Misolampus can be subjected to, their current level of threat has not been evaluated within the frame of the regional IUCN Red List of Mediterranean saproxylic beetles (García et al. 2018).

However, our comparison of historical data with recent records to assess the current population trends of the species of Misolampus, reveals that their distribution ranges show no reduction in the last century, since these species currently persist in most areas of historical occurrence. This fact, combined with the addition of new recent records for some of the species, enables us to state that, from a general perspective, the species 
of Misolampus are not in decline, but rather seem to exhibit an adequate conservation status. This status could be further guaranteed, because the distribution range of all species of Misolampus include numerous protected areas (National and Natural Parks, Natura 2000 protected areas; see https://www.miteco.gob.es/es/biodiversidad/servicios/banco-datos-naturaleza/informacion-disponible/ENP.aspx), which could ensure to some extent the long-term persistence of these saproxylic beetles, if combined with the implementation of adequate agroforestry practices, consistent with the general strategies of saproxylic arthropods conservation from the Mediterranean forests ecosystems (Sánchez Martínez et al. 2012; Marcos García and Galante 2013; García et al. 2018).

Considering the habitat specificity of Misolampus, disjunct distribution records such as Ifni for M. goudotii (Fig. 4), or Cuenca and Valencia for M. subglaber (Fig. 12), can involve threats for the species conservation, derived from local population extinctions, which can be irrevocable in the case of isolated populations. However, disjunct distributions might be not only the result of a reduction of the species range (Teixeira et al. 2018), but also a consequence of recent expansion (Mas-Peinado et al. 2015). Distinguishing between these two situations is highly relevant when evaluating the conservation status of a given species (Hampe and Petit 2005).

\section{Acknowledgments}

We thank Nohemí Percino, Íñigo Martínez-Solano, Gonzalo García, David Buckley, Paula C. Rodríguez Flores, Susette Castañeda, Neus Marí Giner, Miguel Angel Alonso Zarazaga, Pilar Pavón, Carlos Pedraza, and Rodolfo Pérez Rodríguez for field assistance and companionship during field trips. Additional specimens were provided by Alberto Sánchez Vialas, Saúl Yubero, Pablo Barranco, Daniel Ruiz, and Francisco Javier Martínez. We also thank Mercedes París, curator of the MNCN-CSIC, for her help during the revision of the dry-preserved materials from the Entomological Collection and Arabia Sánchez for assistance while taking extended depth-of-focus images at the "Laboratorio de Preparación de Muestras Zoológicas" of the MNCN-CSIC. We thank Andrew Johnston and Luboš Purchart for their comments on the original manuscript. Thanks are due to H.J. Brues for a thorough review of the manuscript language. We acknowledge support of the publication fee by the CSIC Open Access Publication Support Initiative through its Unit of Information Resources for Research (URICI). PMP is supported by MICINN-FEDER through contract BES-2016-077777. This work was partially funded by the project grant PID2019-110243GB-100 (Ministerio de Ciencia e Innovación-FEDER) of Spain to MG-P.

\section{References}

Abellán P, Svenning JC (2014) Refugia within refugia - patterns in endemism and genetic divergence are linked to Late Quaternary climate stability in the Iberian Peninsula. Biological Journal of the Linnean Society 113(1): 13-28. https://doi.org/10.1111/bij.12309 
Alcaráz Ariza F, Peinado Lorca M (1987) España semiárida: Murcia y Almería. In: Peinado Lorca M, Rivas-Martínez S (Eds) La vegetación de España. Servicio de Publicaciones, Universidad de Alcalá de Henares, San Fernando de Henares (Madrid), 257-281.

Antoine M (1926) Notes d'entomologie marocaine. VI (1) Tenebrionides nouveaux et intéressants. Bulletin de la Société des Sciences Naturelles du Maroc 5: 248-259. https://bibdigital.rjb.csic.es/viewer/12177/?offset=\#page=302\&viewer=picture\&o=bookmark\&n=0\&q=

Antoine M (1949) Notes d'entomologie marocaine. 46 Materiaux pour l'étude des Helopinae du Maroc (Col. Tenebrionides). Bulletin de la Société des Sciences Naturelles du Maroc 27 [1947]: 123-162. https://bibdigital.rjb.csic.es/viewer/16061/?offset=\#page=137\&viewer= picture\&o=bookmark\&n=0\&q=

Antoine M (1954) Notes d'entomologie marocaine. LX: sur quelques captures intéressantes (Coléoptères Carabiques et Tenebrionidae). Bulletin de la Société des Sciences Naturelles et Physiques du Maroc 34: 199-209.

Barreda JM (2018) Nuevos datos para la fauna de tenebriónidos en Andalucía (España) (Coleoptera, Tenebrionidae). Boletín de la Asociación española de Entomología 42 (3-4): 237257. http://www.entomologica.es/index.php?d=publicaciones\&num $=73 \& \mathrm{w}=1738 \& \mathrm{ft}=1$

Benabid A (1982) Etudes phytoécologique, biogéographique et dinamique des associations et séries sylvatiques du Rif occidental (Maroc). Thèse Doct. ès-Sc. Faculté des Sciences et Techniques St. Jerôme. Université de Droit, d'Economie et des Sciences d'Aix-Marseille, 199 pp.

Benabid A (1984) Etude phytoécologique des peuplements forestiers et préforestiers du Rif centro-occidental (Maroc). Travaux de l'Institut Scientifique, Rabat, série Botanique 34: 1-64.

Benabid A (1985) Les écosystèmes forestiers, préforestiers et presteppiques du Maroc: diversité, répartition biogéographique et problèmes posés par leur aménagement. Forêt méditerranéenne 7(1): 53-64.

Benabid A (2000) Flore et écosystèmes du Maroc. Évaluation et préservation de la biodiversité. Ed. Ibis Press, Paris, 359 pp.

Benabid A, Fennane M (1994) Connaissances sur la végétation du Maroc: Phytogéographie, phytosociologie et séries de végétation. Lazaroa 14: 21-97.

Benyahia Y, Brustel H, El Antry S, Courtin O, Maatouf N, Valladares L, Rohi L (2016) Preliminary list of Coleoptera heritage species of the Talassemtane National Park, Morocco. Journal of Insect Biodiversity 4(13): 1-30. https://doi.org/10.12976/jib/2015.4.13

Benyahia Y, Soldati F, Rohi L, Valladarès L, Maatouf N, Courtin O, El Antry S, Brustel H (2015) First survey of darkling beetles (Coleoptera, Tenebrionidae) of Talassemtane National Park, Western Rif, Morocco. Check List 11(5): 1778. https://doi.org/10.15560/11.5.1778

Bolòs O de (1997) La vegetació de les Illes Balears. Comunitat des plantes. Institut d'Estudis Catalans, Arxius de les Seccions de Ciències 114 [1996], 269 pp.

Bouchard P, Bousquet Y, Davies AE, Alonso-Zarazaga MA, Lawrence JF, Lyal CHC, Newton AF, Reid CAM, Schmitt M, Slipinski SA, Smith ABT (2011) Family-Group names in Coleoptera (Insecta). ZooKeys 88: 1-972. https://doi.org/10.3897/zookeys.88.807

Bouchard P, Lawrence JF, Davies AE, Newton AF (2005) Synoptic classification of the world Tenebrionidae (Insecta: Coleoptera) with a review of family-group names. Annales Zoologici 55(4): 499-530. http://www.ingentaconnect.com/content/miiz/annales/2005/00000055/00000004/art00001 
Bousquet Y, Thomas DB, Bouchard P, Smith AD, Aalbu RL, Johnston MA, Steiner Jr WE (2018) Catalogue of Tenebrionidae (Coleoptera) of North America. ZooKeys 728: 1-455. https://doi.org/10.3897/zookeys.728.20602

Brême FAG de (1842) Note monographique sur le genre Misolampus. Revue Zoologique 1842: 81-83. https://www.biodiversitylibrary.org/page/14714707

Bujalance De Miguel JL (2015) Estudio taxonómico y ecológico de los Tenebrionidae (coleoptera) del suroeste de la península ibérica: "El caso del rio Guadiamar y de Dońana”. Doctoral dissertation. Universidad De Córdoba, Facultad de Ciencias, Departamento de Zoología. Córdoba, 180 pp.

Cabral MT (1983) Contribuição para o estudo da biodegradação das toiças de Eucalyptus globulus Labill. Doctoral dissertation. Instituto Superior de Agronomia, Lisboa.

Cambefort Y (2006) Des coléopterès, des collections \& des hommes. Publications Scientifiques du Muséum national d'Histoire naturelle, Paris, 375 pp. https://doi.org/10.4000/books. mnhn. 2265

Cárdenas AM (2003) Ciencia y restauración del río Guadiamar. PICOVER 1988-2002. Corredor verde del Guadiamar. Caracterización y seguimiento de la fauna de Coleópteros edáficos del Corredor Verde (cuenca del río Guadiamar). Consejería de Medio Ambiente, Junta de Andalucía, Sevilla, 406-414.

Cárdenas Talaverón AM, Bujalance De Miguel JL (1985) Sobre los tenebriónidos (Col.: Tenebrionidae) de los alrededores del embalse del Bembezar (Sierra Morena de Córdoba). Boletim da Sociedade Portuguesa de Entomología, Actas II Congresso Ibérico de Entomología 3: 497-506.

Cardona Orfila F (1875) Doscientos coleópteros más de Menorca. Imprenta de Miguel Parpal, Maó, 23 pp. https://issuu.com/bibliomao/docs/doscientos_cole_pteros_mas_de_meno

Champion GC (1891) A list of the Heteromerous Coleoptera collected by Mr J J Walker, R N, F L S, in the region of the Straits of Gibraltar, with descriptions of four new species. Transactions of the Entomological Society of London 1891: 375-401. https://www.biodiversitylibrary.org/page/33776818

Charco J (1999) El bosque mediterráneo en el norte de África. Biodiversidad y lucha contra la desertificación. Agencia Española de Cooperación Internacional, Madrid, 370 pp.

Chavanon G (2020) Catalogue des Coléoptères de la région orientale du Maroc (Province de Guercif exceptée). Travaux de l'Institut Scientifique, Série Zoologie 57(2018): 1-192.

Cobos A (1949) Datos para el Catálogo de los Coleópteros de España. Coleópteros de los alrededores de Málaga. Boletín de la Real Sociedad española de Historia Natural 47: 563-609.

Cobos A (1955) Prospección entomológica en la zona española del Protectorado en Marruecos. Archivos del Instituto de Aclimatación de Almería 4: 1-9.

Cobos A (1961) Exploración entomológica del cedral de Tizi-Ifri (macizo del Iguelmalet, Rif central, Marruecos). Coleópteros. Archivos del Instituto de Aclimatación de Almería 10: 63-98.

Costa Tenorio M, Morla Juaristi C, Saínz Ollero H (2005) Los bosques ibéricos. Una interpretación geobotánica. $4^{a}$ Ed. Revisada. Ed. Planeta, Barcelona, 597 pp.

Davies ZG, Tyler C, Stewart GB, Pullin AS (2008) Are current management recommendations for saproxylic invertebrates effective? A systematic review. Biodiversity and conservation 17(1): 209-234. https://doi.org/10.1007/s10531-007-9242-y 
De Carvalho MR, Bockmann, FA, Amorim DS, De Vivo M, De Toledo-Piza M, Menezes NA, De Figueiredo JL, Castro RMR, Gill AC, Mceachran JD, Compagno LJV, Schelly RC, Brito R, Lundberg JG, Vari RP, Nelson G (2005) Revisiting the taxonomic impediment. Science 307(5708): 353. https://doi.org/10.1126/science.307.5708.353b

De La Fuente JM (1934-1935) Fam. Tenebrionidae. In: Catálogo sistemático-geográfico de los Coleópteros observados en la península ibérica, Pirineos propiamente dichos y Baleares (continuación) (Ed.). Boletín de la Sociedad entomológica de España 17[1934]: 17-32, 61-76, 99-114; 18[1935]: 17-32, 53-68, 101-116.

de Oliveira Jr SS, Ortega JC, dos Santos Ribas LG, Lopes VG, Bini LM (2020) Higher taxa are sufficient to represent biodiversity patterns. Ecological Indicators 111: 1-9. https://doi. org/10.1016/j.ecolind.2019.105994

Doadrio I, Araujo R, Sánchez Almazán JI (2019) Las colecciones del Museo Nacional de Ciencias Naturales: investigación y patrimonio. Consejo Superior de Investigaciones Científicas, Madrid, 558 pp. https://doi.org/10.29077/aula/6/sanchez_almazan_invertebrados

Elith J, Graham CH, Anderson RP, Dudík M, Ferrier S, Guisan A, Hijmans RJ, Huettmann F, Leathwick JR, Lehmann A, Li J, Lohmann LG, Loiselle BA, Manion G, Moritz C, Nakamura M, Nakazawa Y, Overton JMcCM, Peterson AT, Phillips SJ, Richardson K, Scachetti-Pereira R, Schapire RE, Soberón J, Williams S, Wisz MS, Zimmermann NE (2006) Novel methods improve prediction of species' distributions from occurrence data. Ecography 29: 129-151. https://doi.org/10.1111/j.2006.0906-7590.04596.x

Elith J, Phillips SJ, Hastie T, Dudik M, Chee YE, Yates CJ (2011) A statistical explanation of MaxEnt for ecologists. Diversity and distributions 17(1): 43-57. https://doi.org/10.1111/ j.1472-4642.2010.00725.x

Erichson WF (1841) Über die Insecten von Algier mit besonderer Rücksicht auf ihre geographische Verbreitung. In: Wagner MF (Ed) Reisen in der Regentschaft Algier 1836, 1837 und 1838 nebst einem naturhistorischen Anhang un einem Kupferatlas. Dritter Band. L. Voss, Leipzig, 140-194. https://www.biodiversitylibrary.org/page/33793901

Escoriza D, Gutiérrez-Rodríguez J, Hassine JB, Martínez-Solano I (2016) Genetic assessment of the threatened microendemic Pleurodeles poireti (Caudata, Salamandridae), with molecular evidence for hybridization with Pleurodeles nebulosus. Conservation genetics 17: 1445-1458. https://doi.org/10.1007/s10592-016-0875-9

Español F (1949) Datos para el conocimiento de los tenebriónidos del Mediterráneo Occidental. VI. El género Misolampus Latr. en Espańa y Baleares. Graellsia 7: 1-7.

Español F (1953) Helopinae de la zona mediterránea de Marruecos (Col. Tenebrionidae). Eos 29: 71-83.

Español F (1954a) Los tenebriónidos (Col.) de Baleares. Trabajos del Museo de Ciencias Naturales de Barcelona, Nueva Serie Zoológica 1(5): 1-93.

Español F (1954b). Coleópteros de Sierra Nevada. Tenebrionidae. Archivos del Instituto de Aclimatación de Almería 2: 111-122.

Español F (1955) Sobre los tenebriónidos gallegos recogidos por el profesor H. Franz. Publicaciones del Instituto de Biología Aplicada 19: 95-103. 
Español F (1956) Contribución al estudio de los tenebriónidos del noroeste de España (Col. Heterómeros). Publicaciones del Instituto de Biología Aplicada 24: 5-71.

Español F (1960) Expedición entomológica J. Mateu, A. Cobos y F. Español a la Sierra de Cazorla. Col. Tenebriónidos. Publicaciones del Instituto de Biología Aplicada 31: 17-32. Español F (1963) El género “Coelometopus” Sol. (Col. “Tenebrionidae”). Archivos del Instituto de Aclimatación de Almería 12: 49-53.

Español F (1967) Misión entomológica Hakan Lindberg y M. Meinander a Marruecos. Col. Tenebrionidae. Publicaciones del Instituto de Biología Aplicada 42: 17-47.

Español F, Comas J (1981) Sobre algunos Tenebriónidos (Col.) del Mediterráneo Occidental. Eos 57: 91-96.

Evenhuis NL (2007) Helping solve the "other" taxonomic impediment: completing the eight steps to total enlightenment and taxonomic nirvana. Zootaxa 1407: 67-68. https://doi. org/10.11646/zootaxa.1494.1.3

Fick SE, Hijmans RJ (2017) WorldClim 2: new 1-km spatial resolution climate surfaces for global land areas. International Journal of Climatology, 37(12): 4302-4315. https://doi. org/10.1002/joc.5086

Fielding AH, Bell JF (1997) A review of methods for the assessment of prediction errors in conservation presence/absence models. Environmental Conservation: 38-49. https://doi. org/10.1017/S0376892997000088

Gaiji S, Chavan V, Ariño AH, Otegui J, Hobern D, Sood R, Robles E (2013) Content assessment of the primary biodiversity data published through GBIF network: status, challenges and potentials. Biodiversity Informatics 8(2): 94-172. https://doi. org/10.17161/bi.v8i2.4124

García N, Numa C, Bartolozzi L, Brustel H, Buse J, Norbiato M, Recalde JI, Zapata JL, Dodelin B, Alcázar E, Barrios V, Verdugo A, Audisio P, Micó E, Otero C, Bahillo P, Viñolas A, Valladares L, Méndez M, El Antry S, Galante E (2018) The conservation status and distribution of Mediterranean saproxylic beetles. IUCN, Málaga, 58 pp. https://doi. org/10.2305/IUCN.CH.2018.RA.3.en

García-López A, Galante E, Micó E (2016) Saproxylic beetle assemblage selection as determining factor of species distributional patterns: implications for conservation. Journal of Insect Science 16(1): 1-7. https://doi.org/10.1093/jisesa/iew030

Gauld ID, O’Neill MA, Gaston KJ (2000) Driving Miss Daisy: the performance of an automated insect identification system. In: Austin AD, Dowton M (Eds) Hymenoptera: evolution, biodiversity and biological control. CSIRO Publishing, Collingwood, 303-312.

Géhu JM, Biondi E (1998) Nature et limites de quelques végétations littorales de type macaronésien sur les côtes sud occidentales du Maroc. Acta Botanica Barcinonensia 45: 439-453.

Gil-Tapetado D, Gómez JF, Cabrero-Sańudo FJ, Nieves-Aldrey JL (2018) Distribution and dispersal of the invasive Asian chestnut gall wasp, Dryocosmus kuriphilus (Hymenoptera: Cynipidae), across the heterogeneous landscape of the Iberian Peninsula. European Journal of Entomology 115: 575-586. https://doi.org/10.14411/eje.2018.055

Gonçalves H, Martínez-Solano I, Pereira RJ, Carvalho B, García-París M, Ferrand N (2009) High levels of population subdivision in a morphologically conserved Mediterranean toad (Alytes cisternasii) result from recent, multiple refugia: evidence from mtDNA, microsatellites 
and nuclear genealogies. Molecular Ecology 18(24): 5143-5160. https://doi.org/10.1111/ j.1365-294X.2009.04426.x

Graells MP (1849) Description de quelques Coléoptères nouveaux de la faune céntrale d'Espagne. Revue et Magasin de Zoologie Pure et Appliquée, série 2, 1: 620-622. https:// www.biodiversitylibrary.org/page/2343470

Graells MP (1851a) Description de quelques coléoptères nouveaux de la Faune centrale d'Espagne. Annales de la Société Entomologique de France, série 2, 9: 5-27. [pl. 1] https:// www.biodiversitylibrary.org/page/14220049

Graells MP (1851b) Descripción de algunos insectos nuevos pertenecientes a la fauna central de España. Memorias de la Real Academia de Ciencias de Madrid, serie 3, [1850], 1(2): 109-163. [pls 8-10]

Grimm R, Aistleitner E (2009) Fragmenta entomofaunistica XVI 1 Schwarzkäfer von der Iberischen Halbinsel (Coleoptera, Tenebrionidae). Nachrichtenblatt der Bayerischen Entomologen 58(3/4): 66-77.

Grixti JC, Wong LT, Cameron SA, Favret C (2009) Decline of bumble bees (Bombus) in the North American Midwest. Biological conservation, 142(1): 75-84. https://doi. org/10.1016/j.biocon.2008.09.027

Guérin-Méneville FÉ (1829-1838) Iconographie du Règne-Animal de G. Cuvier: ou Représentation d'après nature de l'une des espèces les plus remarquables et souvent non encore figurées, de chaque genre d'animaux. Insectes. Baillière, Paris. [pl. 29] https://doi.org/10.5962/ bhl.title. 6255

Guérin-Méneville FÉ (1834) Matériaux pour une classification des mélasomes. (Extraits d'une monographie de cette famille). Magasin de Zoologie 4: 1-39. [pls 101-118] https://www. biodiversitylibrary.org/page/37085196

Guerra-García JM, Espinosa F, García-Gómez JC (2008) Trends in taxonomy today: an overview about the main topics in taxonomy. Zoologica Baetica 19: 15-49. http://hdl.handle. net/11441/28285

Hampe A, Petit RJ (2005) Conserving biodiversity under climate change: the rear edge matters. Ecology Letters 8: 461-467. https://doi.org/10.1111/j.1461-0248.2005.00739.x

Hardin G (1960) The competitive exclusion principle. Science 131: 1292-1297. https://doi. org/10.1126/science.131.3409.1292

Herbst JFW (1799) Natursystem aller bekannten in- und ausländischen Insekten, als eine Fortsetzung der von Buffonschen Naturgeschichte. Der Käfer achter Theil. Commerzien-Raths Pauli, Berlin. 420 pp. [pls 121-137] https://www.biodiversitylibrary.org/ page/57742090

Ibáñez Orrico MA (2002) Algunos coleópteros de la Sierra de Malacara (Valencia). Boletín de la Sociedad Entomológica Aragonesa 30: 182-187.

IUCN (2012) IUCN [International Union for Conservation of Nature] Red List Categories and Criteria: Version 3.1. Second edition. IUCN, Gland and Cambridge, 32 pp. http:// jr.iucnredlist.org/documents/redlist_cats_crit_en.pdf

Izco J (1987) Galicia. In: Peinado Lorca M, Rivas-Martínez S (Eds) La vegetación de España. Servicio de Publicaciones, Universidad de Alcalá de Henares, San Fernando de Henares (Madrid), 385-418. 
Juan C, Petitpierre E (1986) Karyological analyses on tenebrionid beetles from the Balearic Islands. Genetica Iberica 38(3-4): 231-243.

Juan C, Petitpierre E (1989). C-banding and DNA content in seven species of Tenebrionidae (Coleoptera). Genome 32(5) 834-839. https://doi.org/10.1139/g89-519

Juan C, Pons J, Petitpierre E (1993) Localization of tandemly repeated DNA sequences in beetle chromosomes by fluorescent in situ hybridization. Chromosome Research 1(3): 167-174. https://doi.org/10.1007/BF00710770

Kamiński MJ, Kanda K, Raś M, Smith AD (2018) Pythiopina, an enigmatic subtribe of darkling beetles (Coleoptera: Tenebrionidae: Pedinini): taxonomic revision, microtomography, ecological niche models and phylogenetic position. Systematic Entomology 43(1): 147-165. https://doi.org/10.1111/syen.12255

Kholia BS, Fraser-Jenkins CR (2011) Misidentification makes scientific publications worthless - save our taxonomy and taxonomists. Current Science 100(4): 458-461. https://www. jstor.org/stable/24073074

Kirchoff BK, Leggett R, Her V, Moua C, Morrison J, Poole C (2011) Principles of visual key construction - with a visual identification key to the Fagaceae of the southeastern United States. AoB Plants 2011: 1-48. https://doi.org/10.1093/aobpla/plr005

Kocher L (1958) Catalogue commenté des Coléoptères du Maroc. Fascicule VI: Ténébrionides. Travaux de l'Institut scientifique chérifien, série Zoologie 12: 7-185.

Kuussaari M, Bommarco R, Heikkinen RK, Helm A, Krauss J, Lindborg R, ÖCkinger E, Pärtel M, Pino J, Rodà F, Stefanescu C, Teder T, Zobel M, Steffan-Dewenter I (2009) Extinction debt: a challenge for biodiversity conservation. Trends in Ecology and Evolution 24(10): 564-571. https://doi.org/10.1016/j.tree.2009.04.011

Ladero M (1987) La España Luso-Extremadurense. In: Peinado Lorca M, Rivas-Martínez S (Eds) La vegetación de España. Servicio de Publicaciones, Universidad de Alcalá de Henares, San Fernando de Henares, Madrid, 453-486.

Laguna E (1997) Vegetación y flora de la Umbría del Fresnal (Sierra de Malacara, Hoya de Buñol-Chiva). Instituto de Estudios Comarcales Hoya de Buñol-Chiva, Buñol, 141 pp.

Laporte de Castelnau FL (1850) Historie Naturelle des Insectes Coléoptères. Tome II. Premiére Partie. Société Bibliophile, Paris, 272 pp. https:/www.biodiversitylibrary.org/ page/25574301

Latreille PA (1807) Genera crustaceorum et insectorum secundum ordinem naturalem in familias disposita, iconibus exemplisque plurimis explicita. Tomus secundus. Amand Koenig, Parisiis et Argentoratii, 280 pp. https://doi.org/10.5962/bhl.title.65741

Le Houerou HN (1989) Classification écoclimatique des zones arides (s.l.) de l'Afrique du Nord. Ecologia mediterranea 15(3/4): 95-144. [7 pls] https://doi.org/10.3406/ ecmed.1989.1643

Lindberg H (1933) Inventa entomologica, itineris Hispanici et Maroccani, quod a. 1926 fecerunt Harald et Håkan Lindberg. Commentationes Biologicae, Societas Scientiarum Fennica 4(5): 1-31. [1 pl]

Löbl I, Merkl O, Ando K, Bouchard P, Lillig M, Masomuto K, Schawaller W (2008) Subfamily Stenochiinae Kirby, 1837. In: Löbl I, Smetana A (Eds) Catalogue of Palaearctic Coleoptera. Volume 5. Tenebrionoidea. Apollo Books, Stenstrup, 339-352. 
López-Pérez JJ (2014a) Corología del género Misolampus Latreille, 1807. (Col. Tenebrionidae, Tenebrioninae) de la provincia de Huelva (S.O. de Andalucía, España). Arquivos Entomolóxicos 10: 229-234.

López-Pérez JJ (2014b) Corología del género Misolampus Latreille, 1807. (Col. Tenebrionidae, Tenebrioninae) de la provincia de Huelva (S.O. de Andalucía, Espańa). Arquivos Entomolóxicos 10: fe de erratas

López-Pérez JJ (2014c) Contribución al conocimiento de los coleópteros (Coleoptera) de Huelva III - Los Puntales, Paraje Natural de Marismas del Odiel (S.O. de Andalucía, España). Arquivos Entomolóxicos 12: 37-52.

Lucas PH (1849) Exploration scientifique de l'Algérie pendant les années 1840, 1841, 1842: Histoire naturelle des animaux articulés 2, Insectes. Imprimerie Nationale, Paris, 590 pp. https://www.biodiversitylibrary.org/page/46117988

Magurran AE, Baillie SR, Buckland ST, Dick JM, Elston DA, Scott EM, Smith RI, Somerfield PJ, Watt AD (2010) Long-term datasets in biodiversity research and monitoring: assessing change in ecological communities through time. Trends in Ecology and Evolution 25(10): 574-582. https://doi.org/10.1016/j.tree.2010.06.016

Mantle BL, La Salle J, Fisher N (2012) Whole-drawer imaging for digital management and curation of a large entomological collection. ZooKeys 209: 147-163. https://doi.org/10.3897/ zookeys.209.3169

Marcos-García MA, Galante E (2013) Conservación de los insectos saproxílicos del bosque mediterráneo. In: Micó E, Marcos-García MA, Galante E (Eds) Los insectos saproxílicos del Parque Nacional de Cabañeros. Organismo Autónomo de Parques Nacionales, Ministerio de Agricultura, Alimentación y Medio Ambiente, Madrid, 123-139.

Martínez de la Escalera M (1914) Los Coleópteros de Marruecos. Trabajos del Museo Nacional de Ciencias Naturales, Serie Zoológica 11: 1-553.

Martínez Fernández JC (2018) Una puesta al día de los Coleópteros de la familia Tenebrionidae en la Península Ibérica e islas Baleares (Coleoptera). Boletín de la Sociedad Entomológica Aragonesa (S.E.A.) 63: 45-85.

Martínez-Solano I, Teixeira J, Buckley D, García-París M (2006) Mitochondrial DNA phylogeography of Lissotriton boscai (Caudata, Salamandridae): evidence for old, multiple refugia in an Iberian endemic. Molecular Ecology 15(11): 3375-3388. https://doi.org/10.1111/ j.1365-294X.2006.03013.x

Mas-Peinado P, Buckley D, García-París M, Valdeón A, Al-Hemaidi AAM, Castilla AM (2015) Recent mtDNA haplotype diversification in Adesmia cancellata (Coleoptera, Tenebrionidae) across the peninsular desert of Qatar. Zoologischer Anzeiger - A Journal of Comparative Zoology 259: 1-12. https://doi.org/10.1016/j.jcz.2015.09.002

Matthews EG, Bouchard P (2008) Tenebrionid beetles of Australia. Description of tribes, keys to genera, catalogue of species. Department of the Environment, Water, Heritage and the Arts, Australian Government, ABRS, Canberra, 398 pp.

Matthews EG, Lawrence JF, Bouchard P, Steiner WE, Ślipiński A (2010) Tenebrionidae Latreille, 1802. In: Kristensen NP, Beutel RG (Eds) Handbook of Zoology. Arthropoda: Insecta. Volume 2: Coleoptera, Beetles. Morphology and Systematics (Elateroidea, Bosthichiformia, Cucujiformia partim). DeGruyter, Berlin, 786 pp. https://doi.org/10.1515/9783110911213.574 
Médail F, Quézel P (1999) The phytogeographical significance of S.W. Morocco compared to the Canary Islands. Plant Ecology 140: 221-244. https://doi.org/10.1023/A:1009775327616

Meineke EK, Davies TJ, Daru BH, Davis CC (2019) Biological collections for understanding biodiversity in the Anthropocene. Philosophical Transactions of the Royal Society B, Biological Sciences 374: 1-9. https://doi.org/10.1098/rstb.2017.0386

Michard A (1976) Eléments de Géologie marocaine. Notes et Mémories Service Géologique du Maroc 252: 1-408.

Molino Olmedo F (1996) Los Coleópteros saproxílicos de Andalucía. Tesis doctoral. Departamento de Biología Animal y Ecología. Universidad de Granada. Granada, 381 pp.

Montori A, Llorente G, García-París M (2008) Reduced genetic divergence among morphologically differentiated populations of the Pyrenean newt, Euproctus asper (Amphibia: Caudata). Zootaxa 1945: 39-50. https://doi.org/10.11646/zootaxa.1945.1.2

Moore W (2011) Biology needs cyberinfrastructure to facilitate specimen-level data acquisition for insects and other hyperdiverse groups. ZooKeys 147: 479-486. https://doi. org/10.3897/zookeys.147.1944

Moragues F (1889) Coleópteros de Mallorca. Anales de la Sociedad Española de Historia Natural 18[1888]: 11-34. https://www.biodiversitylibrary.org/page/8157089

Mouna M, Arahou M (1986) Comparaison des peuplements de Coléoptères frondicoles de deux essences forestieres resineuses au Maroc: Cedre (Cedrus atlantica Man) et Thuya (Tetraclinis articulata Vahl et Benth). Bulletin de l'Institut Scientifique, Rabat 1: 133-142.

Nabozhenko MV (2015) To the knowledge of Helopini (Coleoptera: Tenebrionidae) of Morocco. Caucasian Entomological Bulletin 11(1): 33-37. https://doi.org/10.23885/18143326-2015-11-1-33-37

Nieto A, Alexander KN (2010) The status and conservation of saproxylic beetles in Europe. Cuadernos de Biodiversidad 33: 3-10. https://doi.org/10.14198/cdbio.2010.33.01

Norton GA, Patterson DJ, Schneider M (2000) LucID: A multimedia educational tool for identification and diagnostics. In: Fernandez A (Ed.) CAL-laborate - A collaborative publication on the use of Computer Aided Learning for tertiary level physical sciences and geosciences. UniServe Science, University of Sydney, Sydney, 15-18.

Novoa F, Gañán I, Campos A, Fernández AB, Santiago M, González J, Baselga A (2014) Coleópteros (Coleoptera) del Parque Natural Serra da Enciña da Lastra (Galicia, noroeste de la Península Ibérica). Boletín de la Asociación española de Entomología 38(1-2): 91-130.

Núñez L, Closa S, González E, Lencina JL, Gallego D (2016) Metodología para la determinación de niveles de infestación por Cerambyx cerdo (Linnaeus, 1758), desarrollo de técnicas de captura y estudio de fauna saproxílica acompañante en los encinares de Mallorca. Cuadernos de la Sociedad Española de Ciencias Forestales 43: 401-408. https://doi. org/10.31167/csef.v0i42.17493

Oliveira JT, Quesada C (2019a) The Geology of Iberia: A Geodynamic Approach: Volume2: The Variscan Cycle. Springer International Publishing, 542 pp. https://doi.org/10.1007/9783-030-10519-8

Oliveira JT, Quesada C (2019b) The Geology of Iberia: A Geodynamic Approach: Volume 3: The Alpine Cycle. Springer International Publishing, 566 pp. https://doi.org/10.1007/9783-030-11295-0 
Palau JM (1945) Notas para un catálogo de los coleópteros de Mallorca. I. Fam. Tenebrionidae. Graellsia 3(1): 23-36.

Palmer M (1998) Phylogeny of the genus Misolampus (Coleoptera: Tenebrionidae). Bolleti de la Societat d' Història Natural de les Balears 41: 139-151.

Palmer M, Cambefort Y (2000) Evidence for reticulate palaeogeography: beetle diversity linked to connection-disjunction cycles of the Gibraltar Strait. Journal of Biogeography 27(2): 403-416. https://doi.org/10.1046/j.1365-2699.2000.00389.x

Palmer M, Petitpierre E (1997) New chromosomal findings on Tenebrionidae (Coleoptera) from the Western Mediterranean. Caryologia 50(2): 117-123. https://doi.org/10.1080/0 0087114.1997 .10797391

Pardo Alcaide A (1955) Contribución al conocimiento de la fauna entomológica marroquí - VI Coleópteros del valle inferior del Uad Muluya. Tamuda 3: 39-74.

París García M, Blay Goicoechea A, Hitado Morales M (2011) Las "especies" no descritas de M. Martínez de la Escalera. In: Martín Albaladejo, Izquierdo Moya (Eds) Manuel Martínez de la Escalera. Biografía y Publicaciones. DVD. Museo Nacional de Ciencias Naturales (CSIC) and Asociación española de Entomología.

Paulino de Oliveira M (1894) Catalogue des Insectes du Portugal. Coléoptères. Imprensa da Universidade, Coimbra, 393 pp. https://www.biodiversitylibrary.org/page/57810657

Peinado Lorca M, Martínez-Parras JM (1987) Castilla-La Mancha. In: Peinado Lorca M, RivasMartínez S (Eds) La vegetación de España. Servicio de Publicaciones, Universidad de Alcalá de Henares, San Fernando de Henares (Madrid), 163-196.

Pérez T, López-Colón JI (2010) Misolampus subglaber Rosenhauer, 1856 (Coleoptera, Tenebrionidae) capturado en una cavidad de Jaén (Andalucía). Arquivos Entomolóxicos 4: 39-41.

Pérez Arcas L (1873). Misolampus goudoti Breme, hallado en Menorca. Actas de la Sociedad Española de Historia Natural 2: 14-15. https://bibdigital.rjb.csic.es/viewer/10480/?offset= \#page=1\&viewer=picture\&o=bookmark\&n=0\&q=

Pérez-Onteniente A, Ibáńez Orrico MA, Montagud Alario S (2015) Nuevos registros de cerambícidos (Coleoptera, Cerambycidae) para la Comunitat Valenciana (este de España). Arquivos Entomolóxicos 13: 75-88.

Pérez-Vera F, Ávila JM (2012) Los Asidini marroquíes. Ensayo monográfico sobre la tribu Asidini (Coleoptera, Tenebrionidae) en el reino de Marruecos. Monografías electrónicas S.E.A., 3: 209 pp. [136 pls] http://www.sea-entomologia.org/monoelec.html

Peyerimhoff P de (1919) Notes sur la biologie de quelques coléoptères phytophagues du nordafricain ( $3^{\text {ème }}$ série). Annales de la Société entomologique France 88: 169-258.

Piochard C (1866) Rapport sur l'excursion faite en Espagne par la Société entomologique de France pendant les mois d'avril, mai et juin 1865. Annales de la Société Entomologique de France, $4^{\text {ème }}$ série 6: 501-544. https://www.biodiversitylibrary.org/page/32544835

Ponder WF, Carter GA, Flemons P, Chapman RR (2001) Evaluation of museum collection data for use in biodiversity assessment. Conservation biology 15(3): 648-657. https://doi. org/10.1046/j.1523-1739.2001.015003648.x

Pons J (2004) Cloning and characterization of a transposable-like repeat in the heterochromatin of the darkling beetle Misolampus goudoti. Genome 47(4): 769-774. https://doi. org/10.1139/g04-019 
Pons J, Petitpierre E, Juan C (1993) Characterization of the heterochromatin of the darkling beetle Misolampus goudoti: cloning of two satellite DNA families and digestion of chromosomes with restriction enzymes. Hereditas 119(2): 179-185. https://doi.org/10.1111/ j.1601-5223.1993.00179.x

Recuero E, García-París M (2011) Evolutionary history of Lissotriton helveticus: Multilocus assessment of ancestral vs recent colonization of the Iberian Peninsula. Molecular Phylogenetics and Evolution 60: 170-182. https://doi.org/10.1016/j.ympev.2011.04.006

Recuero E, Rodríguez-Flores PC (2019) On the geographic distribution of the uncommon Iberian endemic Armadillidium mateui Vandel, 1953 (Crustacea, Isopoda, Armadillidiidae). Graellsia 75: e096. https://doi.org/10.3989/graellsia.2019.v75.239

Reitter E (1917) Bestimmungstabelle der Cossyphini und Misolampini. (Tribus der Tenebrionidae). Wiener Entomologische Zeitung 36(6-7): 129-150. https://doi.org/10.5962/bhl.part.12929

Ricarte A, Jover T, Marcos-García MA, Micó E, Brustel H (2009) Saproxylic beetles (Coleoptera) and hoverflies (Diptera: Syrphidae) from a Mediterranean forest: towards a better understanding of their biology for species conservation. Journal of Natural History 43(9): 583-607. https://doi.org/10.1080/00222930802610527

Rivas-Martínez S (1987) Memoria del mapa de las series de vegetación de España 1:400 000. ICONA, Madrid, 268 pp.

Rivas-Martínez S (2007). Mapa de series, geoseries y geopermaseries de vegetación de España [Memoria del Mapa de Vegetación Potencial de España. Parte I]. Itinera Geobotánica 17(1): 1-436.

Rivas-Martínez S, Costa M (1987) España insular: Las Baleares. In: Peinado Lorca M, RivasMartínez S (Eds) La vegetación de España. Servicio de Publicaciones, Universidad de Alcalá de Henares, San Fernando de Henares (Madrid), 487-513.

Rivas-Martínez S, Díaz TE, Fernández-González F, Izco J, Loidi J, Lousa M, Penas A (2002) Vascular plant communities of Spain and Portugal. Addenda to the syntaxonomical checklist of 2001. Part I. Itinera Geobotanica 15: 5-432.

Rivas-Martínez S, Fernández-González F, Sánchez Mata D (1987) El Sistema Central español: de la Sierra de Ayllón a Serra da Estrela. In: Peinado Lorca M, Rivas-Martínez S (Eds) La vegetación de España. Servicio de Publicaciones, Universidad de Alcalá de Henares, San Fernando de Henares (Madrid), 419-452.

Rodríguez-Flores PC, Jiménez-Ruiz Y, Forró L, Vörös J, García-París M (2017) Non-congruent geographic patterns of genetic divergence across European Branchinecta (Anostraca: Branchinectidae). Hydrobiologia 801: 47-57. https://doi.org/10.1007/s10750-017-3266-4

Rosas-Ramos N, Baños-Picón L, Trivellone V, Moretti M, Tormos J, Asís JD (2019) Ecological infrastructures across Mediterranean agroecosystems: Towards an effective tool for evaluating their ecological quality. Agricultural systems 173: 355-363. https://doi.org/10.1016/j. agsy.2019.03.017

Rosenhauer WG (1856) Die Thiere Andalusiens nach dem Resultate einer Reise zusammengestellt, nebst den Beschreibungen von 249 neuen oder bis jetzt unbeschriebenen Gattungen und Arten. Theodor Blaesing, Erlangen. 429 pp. [3 pls.] https://doi.org/10.5962/bhl.title.66016 Ruiz JL (2015) Presencia de una población singular de Oedemera (Oedemera) hispanica Pic, 1904 (Coleoptera: Oedemeridae) en las Sierras de Tejeda-Almijara (Málaga, sureste de la Península Ibérica) y notas sobre distribución de la especie. Boletín de la Asociación espa- 
ñola de Entomología 39(1-2): 201-210. http://www.entomologica.es/index.php?d=publi caciones\&num $=65 \& \mathrm{w}=1598 \& \mathrm{ft}=1$

Ruiz JL, García-París M (2015) Una nueva especie de Meloe Linnaeus, 1758 del grupo de $M$. (Eurymeloe) rugosus Marsham, 1802 (Coleoptera: Meloidae) del suroeste de Marruecos. Graellsia 71(1): e018. https://doi.org/10.3989/graellsia.2015.v71.118

Sánchez-Montes G, Recuero E, Barbosa AM, Martínez-Solano I (2019) Complementing the Pleistocene biogeography of European amphibians: Testimony from a southern Atlantic species. Journal of Biogeography 46(3): 568-583. https://doi.org/10.1111/jbi.13515

Salata S, Georgiadis C, Borowiec L (2019) Invasive ant species (Hymenoptera: Formicidae) of Greece and Cyprus. North-Western Journal of Zoology 15(1): 13-23.

Salvador RB, Cunha CM (2020) Natural history collections and the future legacy of ecological research. Oecologia 192(3): 641-646. https://doi.org/10.1007/s00442-020-04620-0

Sánchez Martínez C, Benito Peñil D, García de Enterría S, Barajas Catro I, Martín Herrero N, Pérez Ruiz C, Sánchez Sánchez J, Sánchez Agudo JA, Rodríguez de la Cruz D, Galante E, Marcos García MA, Micó E (2012) Manual de gestión sostenible de bosques abiertos mediterráneos con aprovechamiento ganadero. Castilla Tradicional, Valladolid, $148 \mathrm{pp}$.

Sánchez-Piñero F, Pérez Vera F, González Megías A (2013) Los Tenebriónidos (Coleoptera: Tenebrionidae). In: Ruano F, Tierno de Figueroa M, Tinaut A (Eds) Los Insectos de Sierra Nevada. 200 ańos de historia, vol. 2. Asociación española de Entomología, Granada, 61-79.

Sánchez-Vialas A, García-París M, Ruiz JL, Recuero E (2020) Patterns of morphological diversification in giant Berberomeloe blister beetles (Coleoptera, Meloidae) reveal an unexpected taxonomic diversity concordant with mtDNA phylogenetic structure. Zoological Journal of the Linnean Society, zlz164. https://doi.org/10.1093/zoolinnean/zlz164

Sanz de Galdeano C (1997) La zona interna bético-rifeña. Colección Monográfica Tierras del Sur, Universidad de Granada, Granada, 316 pp.

Saoud Z (2020) Can we estimate insect identification ease degrees from their identification key paths? Ecological Informatics 55: 1-5. https://doi.org/10.1016/j.ecoinf.2019.101010 Sebbar A, Hsaine M, Fougrach H, Badri W (2013) Carte des precipitations annuelles au Maroc (1935/2006). 26 ${ }^{\text {éme }}$ Colloque de l'Association Internationale de Climatologie, Cotonou (Bénin), September 2013: 37-43.

Seidlitz G (1867) Einige entomologische Excursionen in den Castilischen Gebirgen im Sommer 1865. Berliner entomologische Zeitschrift 11: 167-178. https://doi.org/10.1002/ mmnd.18670110115

Shea CP, Peterson JT, Wisniewski JM, Johnson NA (2011) Misidentification of freshwater mussel species (Bivalvia: Unionidae): contributing factors, management implications, and potential solutions. Journal of the North American Benthological Society 30(2): 446-458. https://doi.org/10.1899/10-073.1

Short AEZ, Dikow T, Moreau CS (2018) Entomological collections in the age of big data. Annual Review of Entomology 63(1): 513-530. https://doi.org/10.1146/annurev-ento-031616-035536

Solier AJJ (1848) Essai sur les Collaptérides. 14 Tribu - Blapsites. Studi Entomologici 1: 149370. [pls. 6-12] https://www.biodiversitylibrary.org/page/40161343 
Suarez AV, Tsutsui ND (2004) The value of museum collections for research and society. BioScience 54(1): 66-74. https://doi.org/10.1641/0006-3568(2004)054[0066:TVOMCF]2.0.CO;2

Taleb MS, Fennane M (2019) Vascular Plant Communities of Morocco. Phytosociology, Ecology and Geography. In: Pedrotti F (Ed.) Geobotany Studies. Basics, Methods and Case Studies. Springer Nature Switzerland AG. Cham., 1-161. https://doi.org/10.1007/9783-319-93704-5

Teixeira J, Gonçalves E, Ferrand N, García-París M, Recuero E (2018) Mitochondrial phylogeography of the Iberian endemic frog Rana iberica, with implications for its conservation. Current Zoology 64(6): 755-764. https://doi.org/10.1093/cz/zoy010

Valladares L, Calmont B, Soldati F, Brustel H (2013) Contribución al conocimiento de los coleópteros (Coleoptera) de la Provincia de Almería (Andalucía, sureste de España). $2^{\text {a }}$ nota. Boletín de la Sociedad Andaluza de Entomología 22: 25-66.

Valladares LF, Díaz JA, Garrido J (2000) Coleópteros acuáticos del Sistema Ibérico Septentrional (Coleoptera: Haliplidae, Gyrinidae, Dytiscidae, Hydraenidae, Helophoridae, Hydrochidae, Hydrophilidae). Boletín de la Asociación española de Entomología 24(3-4): 59-84. http://www.entomologica.es/index.php?d=publicaciones\&num $=54 \& \mathrm{w}=1074 \& \mathrm{ft}=1$

Valle F (2003) Mapa de Series de Vegetación de Andalucía. Ed. Rueda S.L., Madrid, 131 pp. [1 map]

Valle F, Navarro FB, Jiménez MN (2004) Datos botánicos aplicados a la Gestión del Medio Natural Andaluz I: Bioclimatología y Biogeografía. Manuales de Restauración Forestal n ${ }^{\circ}$. Consejería de Medio Ambiente, Junta de Andalucía, Sevilla, 353 pp.

Vanwalleghem T, Gómez JA, Infante Amate J, González de Molina M, Vanderlinden K, Guzmán G, Laguna A, Giráldez JV (2017) Impact of historical land use and soil management change on soil erosion and agricultural sustainability during the Anthropocene. Anthropocene 17: 13-29. https://doi.org/10.1016/j.ancene.2017.01.002

Vauloger de Beaupré (1900) Contribution au catalogue des coléoptères du Nord de l'Afrique. Helopini. Annales de la Société Entomologique de France 68[1899]: 669-722. https:// www.biodiversitylibrary.org/page/8431237

Velo-Antón G, García-París M, Galán P, Cordero Rivera A (2007) The evolution of viviparity in Holocene islands: Ecological adaptation vs phylogenetic descent along the transition from aquatic to terrestrial environments. Journal of Zoology, Systematics and Evolutionary Research 45(4): 345-352. https://doi.org/10.1111/j.1439-0469.2007.00420.x

Vera JA (2004) Geología de España. Sociedad Geológica de España-Instituto Geológico y Minero de España, Madrid, 890 pp. [2 maps]

Vilgalys R (2003) Taxonomic misidentification in public DNA databases. New Phytologist 160(1): 4-5. https://doi.org/10.1046/j.1469-8137.2003.00894.x

von Heyden L (1870) Entomologische reise nach dem südlichen Spanien, der Sierra de Guadarrama und Sierra Morena, Portugal und den Cantabrischen Gebirgen, mit Bescreibungen der neuen Arten. Herausgegeben von dem entomologischen Vereine. Nicolai'sche Verlagsbuchhandlung, Berlin, 175 pp. https://babel.hathitrust.org/cgi/pt?id=uc1.b3371581\&view=1 up\&seq=6

von Heyden L (1884) Coleopterologische Ausbeute einer Excursion nach der Sierra Espuña. Deutsche Entomologische Zeitschrift 28(2): 355-361. https://doi.org/10.1002/mmnd.48018840122 
Vörös J, Martínez-Solano I, Alcobendas M, García-París M (2006) Mitochondrial DNA phylogeography of Bombina bombina and Bombina variegata in Hungary (Anura: Discoglossidae). Molecular Phylogenetics and Evolution 38: 705-718. https://doi.org/10.1016/j.ympev.2005.08.010

Waters JM, Fraser CI, Hewitt GM (2013) Founder takes all: density-dependent processes structure biodiversity. Trends in Ecology and Evolution 28: 78-85. https://doi.org/10.1016/j. tree.2012.08.024

Wheeler QD (2008) Introductory. Toward the new taxonomy. In: Wheeler QD (Ed.) The New Taxonomy. The Systematics Association, Special Volume Series 76, CSC Press, Boca Raton, 1-17. https://doi.org/10.1201/9781420008562.ch1

Wheeler QD (2013) Are reports of the death of taxonomy an exaggeration? New Phytologist 201: 370-371. https://doi.org/10.1111/nph.12612

Whitehead PF (1993) Observations on Coleoptera of Mallorca, Balearic Islands. Bolletí de la Societat d'Història Natural de les Balears 36: 45-56.

Yackulic CB (2017) Competitive exclusion over broad spatial extents is a slow process: evidence and implications for species distribution modeling. Ecography 40: 305-313. https://doi. org/10.1111/ecog.02836

Yang HP, Ma CS, Wen H, Zhan QB, Wang XL (2015) A tool for developing an automatic insect identification system based on wing outlines. Scientific Reports 5(1): 1-11. https:// doi.org/10.1038/srep12786 